\title{
Media Attention and Stock Categorization: An Examination of Stocks Hyped to Benefit from the Olympics
}

July 6, 2021

\begin{abstract}
We investigate whether there are temporary valuation impacts on stocks that media outlets list as involved in a major sporting event (the summer Olympics). We examine five summer Olympics and identify stocks that media outlets hype as benefiting from the Olympics (Olympic stocks). We find that Olympic stocks exhibit increases in comovement of returns after the announcement of the winning bid and declines in comovements after the games are played, consistent with the Olympics being used by investors as a category for investment. Furthermore, Olympic stock returns outperform their matched counterparts over this time period. If the comovement and valuation benefits are due to changes in underlying economics then we expect to observe corresponding increases in comovements of fundamentals and improvements in profitability. However, we find no observable changes in fundamental comovements or profitability. Consistent with investor sentiment driving the categorization, we find that Olympic firms with a greater retail investor presence have stronger comovements effects; and trading volume and volatility are abnormally high for Olympic firms on days where media outlets have stories linking the firm to the Olympic games. To clarify event-based categorization occurs in other settings where media outlets classify stocks for investment, we show comovement increases for stocks classified as "Stay-at-Home" by analysts and the media and "Meme" by retail investors on the Reddit social media platform.
\end{abstract}

KEYWORDS: Sports events, media, Olympics, Olympic stocks, retail investors, valuation, fundamentals, comovement, categorization, investor sentiment, investor recognition, common factor, Stay-at-Home, Meme.

JEL CLASSIFICATION: G12, G14, and M41.

*We thank an Associate Editor and two referees for helpful comments. We have also received valuable comments from Ted Christensen, Feng Li, Paul Healy, Trevor Harris, James Ohlson, Shiva Rajgopal (Editor), Richard Sloan, and workshop participants at the 2019 Barton Conference held at Columbia University, and the 2016 Annual Conference on Financial Economics and Accounting. 
When Beijing holds its Olympic Games, foreign visitors will fly "Air China" to Beijing, go to "Bank of China" to get cash, take the taxi run by "Beijing Bus", stay at hotels of "China World Trade Center", buy the Olympic toy produced by "HaiXin", eat Peking duck at "QuanJuDe", drink "YanJing Beer", watch TV cable programs from "Beijing Gehua CATV Network", go shopping at "WangFuJing", and return home with Chinese medicines from "Beijing TongRenTang".

Source: Lawtime December 20, 2010.

\section{Introduction}

Mega-sports events such as the Olympics, the FIFA World Cup, and the Super Bowl capture the attention of large sectors of the population. People look forward to watching these events with seats selling for high prices often years before the event takes place. The media coverage of megasports events is extensive with advertising revenues generating large profits for broadcasting networks. In this paper, we focus on five summer Olympics and examine whether the hype and excitement concerning these mega-sports events have spill-over effects into equity valuations. Specifically, we investigate whether investors use the Olympics as a way to identify and classify stocks for investment.

The number of people estimated to watch the Olympics is over 4.6 billion, representing approximately 70 percent of the world's population (Nielsen 2008). Given the global attention, hosting nations often experience significant national pride as the world's focus shifts to that country in the lead-up to the Olympics. We investigate whether the excitement and visibility of the Olympics pushed by the media impact the equity valuations of host-country firms that are expected to benefit from the Olympics (hereafter, "Olympic stocks"). Olympic stocks include those in the airline, construction, hospitality, media, and service industries that either directly or indirectly contribute to the broader Olympic experience.

There are several reasons why we predict that investors will use the Olympics as a way to identify and classify stocks for investment. First, when a country wins a bid, it is common for government officials to discuss the expected economic benefits to the hosting city or country from 
the Olympics. ${ }^{1}$ If investors then infer from this good economic news provided by experts, that certain stocks are likely to disproportionately benefit (those involved in the Olympics), then this news can create new demand for such stocks irrespective of how much the firms actually benefit from the Olympics. Second, the Olympics are an interesting news story for people in hosting countries. Prior to the Olympic games, the media gives frequent updates on the construction progress being made towards the Olympics, gives estimates on the number of tourists that will visit, and discusses other benefits of the games. The media also frequently combines news of the Olympics with the performance of the stock market discussing which companies are likely to benefit and even makes specific lists of such Olympic stocks. This greater media focus is likely to increase investor attention on Olympic stocks and potentially bias them towards selecting these stocks for investment.

We predict that if investors use the Olympics as a category for investment, then the stock returns of Olympic stocks are likely to exhibit increases in comovement among each other. This occurs because investors are no longer purchasing Olympic stocks based on fundamental news but instead are purchasing them based on their "Olympic" attribute. We predict increases in comovement after the winning bid is announced and declines in comovement after the games are played. In addition, if investors are focusing less on fundamental news for these firms, then we predict increases in comovement of Olympic stocks with market indices.

We investigate the pricing of Olympic stocks in five Olympic-hosting countries: Australia (Sydney 2000), Greece (Athens 2004), China (Beijing 2008), the United Kingdom (UK) (London, 2012), and Brazil (Rio, 2016). We start with the Sydney 2000 Olympics since access to information

\footnotetext{
${ }^{1}$ Prior research documents that at the country-level, the benefits to hosting the Olympics are often overstated and the costs are understated, and generally, host-countries go substantially over budget (e.g., Owen 2005; Whitson and Horne 2006; Barclay 2009). This trend appears to be continuing. The 2016 Summer Olympics in Rio de Janeiro went over the initial budget by 14.5 billion reais (3.59 billion USD) and the 2021 Summer Olympics in Tokyo is over initial budget by \$6 billion USD (see, Reuters 2017 and Nikkei Asian Review 2019).
} 
via the internet and on-line trading became more common in the $2000 \mathrm{~s}^{2}$ We focus on the summer Olympic Games because the summer Games are more publicized and have a wider appeal, and consequently, investor awareness of the Olympic stocks is expected to be greater for the summer than the winter Olympics. We classify a stock as an "Olympic stock" as follows. First, we use national and local media, depending on the country, to identify mentions of stocks expected to be involved in or benefit from the Olympic games. Second, we searched investing and social media sites for lists of Olympic theme stocks. Third, we identify all official Olympic sponsors and partners that were publicly traded in the host-country. The main sample across these five Olympics consists of 213 Olympic stocks that were publicly traded as of the Olympic winning bid announcement with 37 Sydney Olympic stocks, 41 Athens Olympic stocks, 60 Beijing Olympic stocks, 60 London Olympic stocks, and 15 Rio Olympic stocks.

We first investigate investor reaction to the Olympics. Consistent with investors viewing the Olympics as having a positive economic benefit to the hosting country, we document that stock market indices rise at the time that the winning bid is announced. There is a seven-year period between the time that a country first learns that it has successfully won a bid to host the Olympics to the playing of the Olympic Games (we term this the Olympic time period). We find that over the Olympic time period, the stocks that media outlets classify as being involved in the Olympics have positive cumulative returns and outperform their matched counterparts by approximately 25 percent. The valuation benefits appear to be permanent since we do not observe them dissipating after the Olympic games are played. Thus, our evidence suggests that investors anticipate positive economic

2 TD Ameritrade, Charles Schwab and Scottrade all started on-line trading businesses in the late 1990's, with approximately 12 online brokerage firms in 1994 and 140 firms by 2001. By the year 2000, almost half of the US population was accessing information on the internet (see, https://ourworldindata.org/internet). The rise of social media also began in the early 2000 with Myspace having a million monthly active users by 2004. 
benefits of the Olympics to these firms and that this heighten investor attention has positive and permanent valuation implications.

We next investigate whether the Olympic classification by the media results in categorization of these stocks by investors. Our first measure of comovement is the average R-squared from firmspecific regressions of Olympic firm returns on an index comprising of all Olympic firms. We find that across the five Olympics, the average R-squared increases by 21.7 percent from the preannouncement period to the year of the Olympic Games with a quick increase in comovement around and after the winning bid announcement which is largely sustained until the Olympic Games. However, consistent with the categorization hypothesis, we find a complete reversal in the increase in R-Squared within the year after the games are played.

Our second measure of comovement is the average R-squared from firm-specific regressions of Olympic firm returns on the market index. We obtain similar results using this measure of comovement. Interestingly, we find that comovement of the propensity-score matched stocks not directly involved in the Olympics (non-Olympic stocks) also increases after the Olympics are announced but to a lesser extent than the Olympic stocks. This finding suggests that our identification of Olympic stocks could be incomplete. This incomplete categorization could be the consequence of investors viewing the Olympics as having broader economic implications for firms in similar industries to those of Olympic stocks or believing that the Olympics benefit the stock market in general. Alternatively, there could be other correlated variables beyond the Olympics that are impacting stock synchronicity.

Our third measure of comovement attempts to control for general trends in stock synchronicity. This measure is based on the average betas from firm-specific regressions of an Olympic firm's stock return on an Olympic Index and a non-Olympic Index. We find that the beta 
on the Olympic Index increases after the winning bid announcement by approximately 10 percent and continues to increase to approximately 27 percent by the year of the Olympic games while the beta on the non-Olympic Index decreases by over 35 percent over this same period. Thus our results across the three metrics suggest that comovements increase for Olympic stocks.

After establishing the stock market impact of the Olympics, we investigate whether these effects are also reflected in underlying firm fundamentals. We find no evidence of abnormal profitability or growth for Olympic firms during the Olympic period. Earnings and revenues of Olympic stocks are similar to those of matched firms in all periods leading up to and during the Olympic year. In addition, we find little to no evidence that fundamentals (earnings or revenues) of Olympic stocks comove with each other more strongly during the Olympic period. The lack of results for fundamentals could be due to us having low power tests since data is only available on a quarterly or semi-annual basis. However it could also be the case that the Olympics games do not result in detectable levels of abnormal profitability or fundamental comovement risk since (i) the Olympic games only last 16 days; and (ii) Olympic firms come from a variety of industries and so differ in the timing of benefits and risks associated with the Olympics (e.g., a construction firm's profits will depend on the negotiated contract earned before the games, whereas hotels and restaurants profits are dependent on tourism and are earned around the time of the games); and (iii) the press and more recently, social media outlets are the source of the classification of firms benefiting from the Olympics and not the firms themselves.

An alternative explanation for the comovements and valuation effects is that retail investors use media outlets as a source of information for identifying stocks for investment. These investors do not buy these stocks based on an analysis of the fundamental benefits of the Olympics but instead purchase these stocks because they believe the story that a major sporting event will create value for 
stocks involved in the Olympics. Consistent with media-driven investor sentiment, we show that (i) the comovements effects that we document are stronger for firms that have a greater retail investor base; and (ii) on days were the media has a story linking the Olympics to a firm, there are abnormal increases in stock volatility and trading volume for that firm. These results support the conjecture that investors are purchasing these stocks based on their "Olympic" characteristic rather than based on their fundamentals. However, we hesitate in attributing the findings to investor naivete since the valuations of Olympic stocks do indeed increase. This suggests that the media story of valuation benefits becomes a self-fulfilling prophesy when a sufficient number of investors believe the story and are willing to buy and hold these stocks. ${ }^{3}$

Our analyses focus on five summer Olympics and in further tests we investigate whether our findings generalize outside our sample in two ways. First, we show that comovements changes also have occurred in Olympic stocks in Japan - the country holding the next Olympics. Second, we show increases in comovement for stocks that are classified by regular media outlets as "Stay-atHome" stocks and by retail investors on social media sites as "Meme" stocks. These results support our contention that media hype and retail investor attention are key mechanisms for driving the investor categorization.

Our paper makes two contributions to the literature. First, we provide evidence consistent with the model developed in Barberis and Shleifer (2003) that investors group assets into categories when investing. To date, most research testing categorization has focused on stocks moving in and out of indices (e.g., S\&P 500) or focused on a specific industry (e.g., internet stocks) or firms

\footnotetext{
${ }^{3}$ If investor demand for the categorized stock results in stock price increases that are not supported by fundamentals, the high stock price itself can be used by managers to create fundamental value. This is achieved by issuing shares. For example, due to the pandemic AMC Entertainment was close to bankruptcy and heavily shorted, but after it became a Meme stock and its price rose from $\$ 2$ to $\$ 57$ AMC sold shares to Mudrick Capital management for \$230.5 million. Management plan to use the capital infusion for investment and deleveraging the balance sheet. Thus the infusion of cash reduced bankruptcy risk for AMC (see its 8-K filed on June 1, 2021).
} 
switching the geographic location of their headquarters. ${ }^{4}$ Our tests of the Olympics provide a new way of thinking about categorization because it classifies stocks across different industries; and we predict temporary comovement changes based on an event that occurs on a different date in different countries. Our event-based approach allows us to develop more powerful tests because we can rule out many competing explanations for comovement changes.

Second, our study highlights that event-based media or social-media attention of certain stocks combined with a significant retail investor base can lead to investor-based categorizations. This categorization can benefit the firm because the increase investor interest can result in abnormal volume and increases in valuation. However, it also results in increases in the comovements of returns, suggesting that prices are being less influenced by underlying fundamentals. Overall, our findings suggest that if retail investors continue to categorize certain stocks together, we will continue to observe valuation changes that do not necessarily reflect fundamental-driven comovements risk or profitability.

2. Related Research and Predictions

\subsection{Media Attention and Olympic Stocks}

Prior research suggests that the valuation of individual stocks is impacted by investor awareness (e.g., Merton 1987; Hirshleifer and Teoh 2003; Bloomfield 2002; Barber and Odean 2008). There are many companies that investors can potentially buy and as a consequence, investors only know about a subset of available securities. Institutional investors and hedge funds can increase their knowledge of firms by screening companies using financial reporting information and other

\footnotetext{
${ }^{4}$ Vijh (1994) and Barberis, Shleifer, and Wurgler (2005) analyze stocks moving in and out of the S\&P500. Cooper, Dimitrov, and Rau (2001) analyzes firms that change their name to dot.com but do not change their business models. Pirinsky and Wang (2006) examine changes in a firm's geographic location. Other researchers have examined market efficiency questions using comovement of returns of: closed end funds (e.g., Lee, Shleifer, and Thaler 1991); and investor attention - based on measures such as business press articles, EDGAR downloads, and Google searches (Drake, Jennings, Roulstone, and Thornock 2017).
} 
metrics. However, many investors (both retail and institutional investors) are likely to identify potential investments based on their familiarity with the company's products (e.g., Apple's iphone); specific causes (e.g., solar energy, social responsibility); or firms with more media coverage and press dissemination (e.g., Kalay 2015). Consequently, increasing firm visibility can impact market attributes of firms such as institutional holdings, trading volume, bid-ask spreads, stock price volatility, and valuation. Lehavy and Sloan (2008) for example, find that firm visibility measures appear to be more important in explaining prices than firm fundamentals.

Related to the benefits of visibility, a growing body of literature suggests that the media provides a key role in identifying and rebroadcasting firm-specific financial information which in turn can affect investor trading and stock prices (e.g., Antweiler and Frank 2004; Barber and Odean 2008; Birz and Lott 2011; Engelberg and Parsons 2011; Li, Ramesh, and Shen 2011; Lawrence, Ryans, Sun, and Laptev 2018); reduces information asymmetry (e.g., Bushee, Core, Guay, and Hamm 2010); and sheds light on accounting frauds (e.g., Miller 2006; Dyck, Morse, and Zingales 2010). However, greater media attention also has the potential of amplifying problems with pricing. For example, using over-the-counter Nasdaq market maker data from 2003 to 2007, Tetlock (2011) finds evidence suggesting that short-term weekly return reversals are partly explained by individual investors overreacting to stale news. Barberis, Shleifer, and Vishny (1998) and Li and Yu (2012) find that investors appear to overreact to consistent patterns of news. Solomon, Soltes, and Sosyura (2014) find that media coverage can exacerbate investor bias to allocate money to funds with high past returns. These research findings suggest that the media can increase investor awareness of stocks but such awareness can also result in an overreaction to information.

The Olympics is a sporting event that has strong public interest and is a focus of much media attention. We predict that business media outlets are likely to discuss and publicize companies that 
potentially benefit from the Olympics. Indeed, in China there were dedicated websites and chatrooms that focused on the Olympics and stocks that benefit from the Olympics. If a sufficient number of investors focus on the "story" of the financial benefits of the Olympics discussed by the media, rather than carefully analyzing the potential cash flow benefits of the Olympics to individual firms, then circumstances are created where potential categorization can occur.

Barberis and Shleifer (2003) suggest that to simplify portfolio decisions, investors group stocks into categories or "styles" and then allocate funds at the level of the category rather than at the individual asset level. Following Barberis and Shleifer (2003) and Barberis, Shleifer, and Wurgler (2005, p. 284) we suggest that: if investors: (i) use the Olympics as a way to categorize stocks for investment; (ii) have correlated sentiment; and (iii) have a level of trading activity sufficient to affect prices; then as they move funds into and out of Olympic stocks, their demand will induce a common factor in the return of firms that are classified in the same "Olympic" category. Consequently, we expect to observe an increase in comovement among Olympic stocks after the winning bid is announced. This prediction assumes that after the Olympics are announced there is greater investor awareness of stocks involved in the Olympics via the media or social media, and in turn affects investment decisions. Additionally, after the Olympic Games are played and the Olympic categorization is no longer relevant, we expect to see declines in return comovement. This leads to the following prediction:

P1: $\quad$ After a host country announces a winning bid for the Olympics, investors classify firms that are expected to benefit from the Olympics into a category for investment.

P2: $\quad$ After the Olympic Games are played, investors in the host country no longer classifying firms that are expected to benefit from the Olympics into a category for investment.

We operationalize categorization by analyzing comovements in returns. We provide several measures of comovement. The first measure is the average R-squared from Olympic-firm-specific 
regressions of stock returns on an index of Olympic stocks. This measure of comovement is similar in spirit to the approach adopted by Barberis, Shleifer and Wurgler (2005) that examine firms entering or leaving the S\&P500 Index. An increase in comovement is consistent with investors using the Olympics as a category for investment. Our second measure of comovement is the R-squared from a regression of a firm's stock return on a market index (e.g., Roll 1988). A higher correlation indicates that more of the return to a stock is explained by market-wide factors and less by firmspecific factors. Prior research provides evidence that comovement is impacted by changes in the information environment (e.g., analyst following - Chan and Hameed 2006; Crawford, Roulstone, and So 2012; Muslu, Rebello, and Xu 2014; Hameed, Morck, Shen, and Yeung 2015) and the level of sophistication of investors (e.g., Morck et al. 2000; Kumar and Lee 2006; Kumar, Page, and Splat 2013). In our setting, if investors categorize Olympic stocks together then the stock prices of Olympic stocks will become less sensitive to firm-specific news and more sensitive to market-wide news that could have implications for the Olympics. Our third measure of comovement is based on the average betas from firm-specific regressions of Olympic-firm stock returns on an index of Olympic stocks and an index of non-Olympic stocks. If comovement increases among Olympic stocks, then we could see increases in the beta on the Olympic Index and declines in beta on the nonOlympic Index (e.g., Barberis, Shleifer, and Wurgler 2005). Our fourth measure of comovement is a measure of synchronicity (Morck et al. 2000) which is the maximum percent of Olympic stock returns that are the same sign (positive, negative, or zero) in a given month. We provide this measure in some of our figures as a complement to our first measure of comovement.

\subsection{The Fundamental Benefits of the Olympics}

It is an empirical question how much companies and countries economically benefit from holding the Olympics. There is no question that there are benefits to certain firms from being 
involved in the Olympics. However, the dollar magnitude of the benefits and the timing of benefits will vary across firms. For example, hotels benefit from increased tourism occurring at the time of the games, while construction companies benefit from government contracts before the games. The anticipated number of tourists and athletes could vary over time as news is released about wars, disease, political disagreements, oil prices, etc., but the games only last for two weeks and the hotels, airplanes, restaurants, and shops have capacity constraints. Thus, although there is a good "story" for why Olympic stocks will benefit from the Olympics, the actual impact on fundamentals could be small and transitory relative to a firm's entire year's earnings or revenues. We therefore investigate whether Olympic stocks earn abnormal/unusual earnings and revenues during the seven-year Olympic period and whether their fundamentals appear to co-move with each other. Our predictions in alternative form are:

P3: Firms that are classified into the Olympic category by investors exhibit improvements in fundamentals over the Olympic time period.

P4: $\quad$ Firms that are classified into the Olympic category by investors exhibit positive comovements of fundamentals over the Olympic time period.

3. Data and Sample

\subsection{Identifying Olympic Stocks}

We identify those stocks that the media has categorized as an "Olympic stock" using the following procedures. First, for all Olympics except for the Beijing Olympics, we categorized Olympic stocks by searching local and national media in the host country to identify media mentions of stocks expected to be involved or benefit from the Olympic games. For the Sydney Olympics, we use Factiva, for the Athens Olympics we used local media sources such as https://www.kathimerini.gr/, https://www.tanea.gr/ and https://www.naftemporiki.gr/. For the London Olympics we use the Financial Times and for the Rio 2016 Olympics, we used Bloomberg 
and local media sources such as https://www.infomoney.com.br/. Second, for the Beijing Olympics

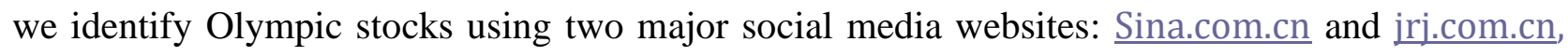
which created lists of Olympic theme stocks that were expected to be directly or indirectly involved in the Olympics. The categorization is done by the websites and the media and not by the firms. In other words, the involvement of firms in the Olympics and the economic benefits from their involvement could vary widely across the firms placed in the Olympic category. Third, we identify all official Olympic sponsors, and where possible partners, that were publicly traded in the hostcountry. All stocks identified in these three procedures are categorized as Olympic stocks.

We require both Olympic and non-Olympic stocks to be listed at the time of the Olympic bid announcement and have financial data available prior to the bid announcement. This requirement allows us to examine whether financial performance of these firms appears to improve following the Olympic bid win announcement. It also allows us to compare market valuations more easily over time. We require the availability of monthly stock returns, annual earnings and revenues following the bid announcement until three years after the Olympics. We obtain stock return and financial data from Factset and Datastream. After applying the foregoing selection criteria, the main sample across these five Olympics consists of 213 Olympic stocks that were publicly traded as of the Olympic winning bid announcement with 37 Sydney Olympic stocks, 41 Athens Olympic stocks, 60 Beijing Olympic stocks, 60 London Olympic stocks, and 15 Rio Olympic stocks. Appendix A provides examples of firms classified as Olympic stocks. To facilitate a difference-in-difference identification strategy, we match each Olympic stock to a non-Olympic stock using 1:1 propensity-score matching including industry fixed effects. ${ }^{5}$ We match on firm characteristics one year before the Olympics

\footnotetext{
${ }^{5}$ The main Olympic comovement inferences are robust to using coarsened exact matching (CEM) rather than propensity-score matching. We did not replicate all tests using CEM because this would require additional hand-collection of data for peer firms.
} 
announcement: total assets, market capitalization, book-to-market, earnings-to-price, ROA and CFO.

\subsection{Olympics Covered, Industry Classifications, and Descriptive Statistics}

Table 1, Panel A provides information on the five Olympics covered including the key Olympic dates and the major stock market indices used for each respective Olympic analysis. Our main sample includes the following five summer Olympics since 2000: Sydney (2000), Athens (2004), Beijing (2008), London (2012), and Rio (2016). Panels B and C provide the industry composition of Olympic and non-Olympic stocks. The table indicates that Olympic stocks are most represented in the construction, real estate development, and hospitality industries, which is consistent with the types of services required to support the Olympics. Panel D of Table 1 provides the descriptive statistics for Olympic and non-Olympic stocks and illustrates that the 1:1 propensityscore matching was effective at balancing Olympic and non-Olympic stocks given the insignificant differences across the mean and median values of all firm-level characteristics. The mean Olympic stock has total assets and a market capitalization of $\$ 5.3$ billion and $\$ 1.7$ billion USD respectively, and a book-to-market and earnings-to-price multiples of 0.86 and 0.04 , respectively. Additionally, it is profitable and has positive cash flow from operations.

\section{Empirical Results}

\subsection{Stock Markets and the Olympic Games}

We first provide a broad perspective of the timing of the Olympic Games and the state of the stock markets around the world. Figure 1 plots the MSCI World Index from 1988 until 2020. This index represents large and mid-cap equity performance across 23 developed markets countries. We include the winning bid announcement dates for nine summer Olympics (Atlanta, Sydney, Athens, Beijing, London, Rio, Tokyo, Paris, and Los Angeles) along with the dates of the games for the six most recent games. Our main sample consists of the five most recent summer Olympics (Sydney 
August, 2000; Athens August, 2004; Beijing August, 2008; London July/August, 2012; and Rio August, 2016) and in the Additional Analyses section, we provide preliminary evidence on the Tokyo Olympics which was postponed until the summer of 2021.

Figure 1 highlights that there are three major stock market expansions over this time period. The first peak is in mid-2000 and reflects the dot.com bubble. This bubble peaks around the time of the Sydney Olympic Games. When China learns it has won the Olympic bid in July 2001, markets are in a contraction period. The games in Athens are played as markets are rising, and by the time London learns of its winning bid (July 2005), markets have been rising for several years. The second peak in the MSCI is in mid-2007 and reflects the real estate boom. The Olympic Games are played in Beijing as markets are rapidly declining as the financial crisis begins to unfold. ${ }^{6}$ Markets have generally been rising since 2009 and are increasing at the time that the London games were held (July 2012). Markets have continued to rise after 2012. This figure highlights that the stock market situation during the Olympic period and at the time of the winning bid announcements are quite different for the five Olympics, mitigating the likelihood that any common results we document across the five countries are due to other market-wide trends.

Figure 2 provides descriptive evidence of the market response to the Olympic games for our main sample of the five most recent Summer Olympics. Panel A provides the average return for the Olympic stocks, propensity-score matched non-Olympic stocks, and the market index in the host country to the announcement of the winning bid. The figure indicates that the news of the winning bid has an impact on markets and viewed positively by market participants. The firms that are expected to benefit from the Olympics have stronger ten day returns (471 basis points) than the

\footnotetext{
${ }^{6}$ On June 22, 2007, Bear Stearns revealed that two of its subprime mortgage funds needed collateral and that it was pledging a collateralized loan of up to $\$ 3.2$ billion to "bail out" one fund and negotiating with other banks to loan money for another fund (for more details see for example: http://www.nytimes.com/2007/06/23/business/23bond.html). This revelation is generally viewed as the starting point for revisions in expectations about real-estate values and the value of mortgage-backed securities.
} 
matched non-Olympic (441 basis points) firms or the market index (378 basis points).

Panel B of Figure 2 provides the average stock market response during the two-week period when the games are played. There are negative returns of -437 basis points for Olympic and -247 basis points for the matched non-Olympic stocks over the two-week window. For the market index there is generally a slight negative return over the first week of the Olympic games but the returns recover in the second week and end flat by the closing day of the Olympics. Panel C of Figure 2 provides the stock market response in the month after the games are played. The completion of the games is associated with negative returns for Olympic stocks ( -367 basis points), non-Olympic stocks (-337 basis points), and the stock market (-175 basis points).

[Figure 1 and 2]

Figure 3 provides descriptive evidence on the differences in cumulative returns between Olympic and non-Olympic stocks across the five summer Olympics, from the year of the winning bid announcement through to a year after the Olympics. Cumulative returns for both Olympic and non-Olympic stocks are calculated as the monthly compounded returns. Figure 3 highlights that even in the lead up to the official winning bid announcement Olympic stocks start to outperform their non-Olympic counterparts and continue to do so over the entire Olympic period. The outperformance reaches a high of approximately 60 percent during the buildup to the Olympic games but tails off to approximately a 25 percent outperformance by the time of the Olympics. Figure 3 shows little evidence to suggest that this Olympic premium dissipates in the year following the Olympics, and while the returns continue to increase in the year after the Olympics for Olympic stocks relative to non-Olympic stocks, these increases are statistically insignificant. Additionally, the requirement that both the Olympic stock and its non-Olympic stock peer are publicly traded for the entire Olympic period mitigates concerns that the increases in returns for Olympic stocks is a consequence of 
survivorship bias. In untabulated analyses, we find that the outperformance of Olympic stocks during the Olympic period holds separately for four out of the five summer Olympic games. The London Olympics was the only Games where Olympic stock returns underperformed (by 7.55 percent) those of non-Olympic stocks.

In summary, Figure 2 and 3 highlight that investors are aware of the Olympics and appear to view the announcement of the Olympics as good news for the hosting country but then bad news once the Olympics is taking place and has passed. Additionally, these findings illustrate that our matched sample approach used in our main analyses could be dampening the economic magnitude of our main Olympic categorization findings as it appears that the entire market, including the nonOlympic stocks, experience broader market effects from the anticipated benefits of the Olympics and that the effects are not just limited to Olympic stocks. Figure 3 further suggests that the valuation benefits to Olympic stocks do not reverse after the Olympic games are played.

[Figure 3]

\subsection{Comovement of Returns during the Olympic Period}

This section provides our tests examining whether Olympic stocks experience changes in comovement during the Olympic time period. We divide the Olympic period into the following subperiods: Pre-Announcement Years: a three-year window prior to the announcement of the winning bid; Middle Years: the years after the announcement of the winning bid until the time the year of the Olympic games (approximately a seven-year window); Olympic Years: the year of the Olympic games; Post-Game Years: a three-year window after the games are played.

Our first measure of comovement is the R-squared from a regression of an individual Olympic firm $i$ 's daily stock return on an index comprising the returns of all Olympic stocks 
(OlympicIndex) in each country $k$ (except stock $i)$.

Model 1a: Olympic Stock Return ${ }_{i, t, k}=\alpha_{0}+\beta_{i}$ Olympic Index $x_{t, k}+\varepsilon_{i, t, k}$

If the greater media coverage of the Olympics and potential Olympic benefiting stocks increases investor awareness of these stocks and this leads a subset of investors to categorize Olympic stocks together then for Olympic stocks we expect to observe (i) an increase in R-squared in the Middle Years and Olympic Years relative to the Pre-Announcement Years; and (ii) declines in the R-squared in the Post-Game Years relative to the Olympic Years. This approach to evaluating categorization is similar to Barberis, Schleifer, and Wurgler (2005) who evaluate changes in R-squared for stocks entering and leaving the S\&P500 index. We repeat this procedure with non-Olympic stocks in Model $1 \mathrm{~b}$ to serve as a benchmark and facilitate the difference-in-differences multivariate analyses:

Model 1b: Non-Olympic Stock Return $n_{i, t, k}=\alpha_{0}+\beta_{i}$ Non-Olympic Index $x_{t, k}+\varepsilon_{i, t, k}$

Our second measure of comovement is the R-squared from a regression of an individual Olympic firm $i$ 's stock return on the market return (Market Index) in country $k$ :

Model 2a: Olympic Stock Return $i_{i, t, k}=\alpha_{0}+\beta_{i}$ Market Index $_{t, k}+\varepsilon_{i, t, k}$

An increase in R-squared in Model 2a suggests that more of the variation in firm $i$ 's return is driven by market-wide forces (such as changes in risk or expected returns; country-wide news about changes in fundamentals that affects all firms; or changes in market sentiment). In other words, a higher R-squared indicates that the Olympic firm's return is driven less by firm-specific news and more by market-wide forces (e.g, Morck, Yeung, and Yu 2000; Durnev, Morck, and Yeung 2004). MarketIndex is calculated as the daily market returns for each country $k$ where the following indices are used: ASX All for Sydney (2000); ATHEX Composite for Athens (2004); Shanghai A Share or Shenzhen Index for Beijing (2008); FTSE All Shares or AIM index for London (2012); and 
BOVESPA Index for Rio (2016). We predict (i) an increase in the R-squared in the Middle Years and Olympic Years relative to the Pre-Announcement Years; and (ii) declines in the R-squared in the Post-Game Years relative to the Olympic Years.

Stock market comovements are likely to be affected by many factors and so we also provide the following regression that examines the R-squared of non-Olympic stocks with the market return: Model 2b: Non-Olympic Stock Return $n_{i, t, k}=\alpha_{0}+\beta i$ Market Index ${ }_{t, k}+\varepsilon_{i, t, k}$

We expect to observe (i) greater increases in the R-squared during the Middle Years and Olympic Years relative to the Pre-Announcement Years for Olympic firms relative to non-Olympic firms (i.e., the average difference in difference is positive (Model 2a: $\Delta \mathrm{R}$-squared $>$ Model 2b $\Delta \mathrm{R}$ squared); and (ii) greater declines in the R-squared after the games are played for Olympic firms relative to the Olympic Years (i.e., the average difference in difference is negative (Model 2a: $\Delta R$ squared $<$ Model $2 \mathrm{~b}$ : $\Delta \mathrm{R}$-squared). Note that these tests assume that we have correctly classified Olympic and non-Olympic stocks. If investors view some of the non-Olympic stocks as benefiting from the Olympics then this will reduce the power of our difference in difference tests.

The first and second measure of comovement discussed above rely on and focus on changes in R-squareds. Our third measure of comovement is based on a bivariate regression that analyzes changes in the magnitude of beta coefficients. We perform the following regression of an individual firm $i$ 's daily stock return on an index comprising of the returns of all Olympic stocks (except stock i) and an index comprising of the returns of non-Olympic stocks:

Model 3: Olympic Stock Return ${ }_{i, t, k}=\alpha_{0}+\beta_{l i}$ Olympic Index $_{t, k}+\beta_{2 i}$ Non-Olympic Index ${ }_{t, k}, \varepsilon_{i, t, k}$

The advantage of Model 3 is that this bivariate regression can help "distinguish the fundamentals-based theory of comovements from a friction -or sentiment-based theories" (Barberis 
et al. 2005, p. 297). ${ }^{7}$ Under a sentiment-based view, controlling for the returns on non-Olympic stocks, an Olympic stock will experience a larger loading on the Olympic Index after the winning bid is announced. Therefore, we expect to observe (i) a positive change in the coefficient on the Olympic Index after the winning Olympic bid is announced relative to the Pre-Announcement Years and a negative change in the coefficient on the non-Olympic Index (i.e., $\Delta \beta_{1 i}>0$ and $\Delta \beta_{2 i}>0<0$ ); and (ii) a decline in the coefficient on the Olympic Index and an increase in the coefficient on the non-Olympic Index after the games are played relative to the Olympic Years (i.e., $\Delta \beta_{1 i}>0<0$ and $\left.\Delta \beta_{2 i}>0>0\right)$. Note again, that this test assumes that we have correctly categorized firms into Olympic and non-Olympic stocks. If some of the non-Olympic firms are viewed by investors as benefiting from the Olympics (e.g., firms in similar lines of business or in the same industry), then this will reduce the power of our tests concerning $\Delta \beta_{2 i}>0$.

The final comovement measure, Synchronicity, which we use in figures to complement our first comovement measure follows the procedure adopted by Morck et al. (2000) and it measures the maximum fraction of Olympic stocks (or Non-Olympic stocks) that move in the same direction over a given month in country $k$ and is calculated as follows:

Model 4a: Olympic Synchronicity ${ }_{t, k}=1 / T \sum_{t} \max \left[\eta_{k t}^{\text {up }}, \eta_{k t}^{\text {down }}, \eta_{k t}^{\text {same }}\right] /\left[\eta_{k t}^{u p}+\eta_{k t}^{\text {down }}+\eta_{k t}^{\text {same }}\right] \quad$ (4a) Model 4b: Non-Olympic Synchronicity $t, k=1 / T \sum_{t} \max \left[\eta_{k t}{ }^{u p}, \eta_{k t}{ }^{d o w n}, \eta_{k t}^{\text {same }}\right] /\left[\eta_{k t}{ }^{u p}+\eta_{k t}{ }^{\text {down }}+\eta_{k t}^{\text {same }}\right](4 b)$

$\eta_{k t}^{u p}$ is the number of stocks whose prices rise in period $\mathrm{t}$ in country $\mathrm{k}, \eta_{k t}{ }^{\text {down }}$ is the number of stocks whose prices fall, and $\eta_{k t}^{\text {same }}$ is the number of stocks whose prices stay the same, and $T$ is the number of periods used.

Table 2 provides results for Model (1) and reports the R-squares for each of the four Olympic

\footnotetext{
${ }^{7}$ Barberis et al. (2005) introduce this test to investigate whether investors treat a stock differently after it is added or subtracted from the S\&P500 index. A stock's fundamental characteristics does not change when it is added to the S\&P500 Index, but Barberis et al. (2005) find that the stock's loading on the S\&P500 Index increases consistent with a sentiment-based explanation.
} 
time periods and below we report the change in R-squares between sequential periods along with significance levels (p-values). Consistent with Prediction P1, we find that the comovement of Olympic stocks with the Olympic index increases from 0.226 in the Pre-Announcement period to 0.264 in the Middle Years and then further increases to 0.283 in the Olympic Years, representing a total increase of 25.2 percent from the Pre-Announcement Years to the Olympic Years. Both of these increases are significant at the five-percent level using one-tailed tests-which are used given we have specific predictions. Consistent with Prediction $P 2$, we find a complete reversal in the increase in R-Squared within a year after the games are played. Specifically, there is a significant decline in average R-squares after the games decreasing from 0.283 in the Olympic Years to 0.204 the PostGames period.

Figure 4 provides graphical representations of the changes in comovement of Olympic stocks. For each firm, for each month, we perform Regression (1) using daily stock returns for the prior year, we then calculate the average R-squared and move forward one month and repeat the procedure. This methodology gives us monthly average measures of comovement and we then plot these averages on the graph. We follow the same procedure with the Synchronicity measure described above. Both the R-squared and synchronicity measures in Figure 4 reiterate Table 2's inferences, illustrating a clear increase in comovement for Olympic stocks after the winning bid is announced, which is largely sustained despite some oscillation until the Olympic Games. However, consistent with the categorization hypothesis, we find a complete reversal in in both comovement measures within a year following the Olympics.

[Table 2 and Figure 4]

Table 3 provides the R-squareds from Models (2a) and (2b) across the four Olympic periods. The results indicate that Olympic firms have larger increases in comovement with the market index 
from the Pre-Announcement Years to both the Middle Years and Olympic Years relative to nonOlympic firms, highlighting that firm-specific information explains less of the return variation for Olympic stocks after the winning-bid announcement. The change in R-squared from the PreAnnouncement Years to the Middle Years is 0.027 for Olympic firms and 0.010 for non-Olympic firms, representing a difference-in-difference increase of 0.016 (significant at the five-percent level). The change in R-squared from the Middle Years to the Olympic Years is 0.028 for Olympic firms and 0.022 , representing a difference-in-difference increase of 0.006 which is significant at the tenpercent level. After the Olympic games are played, we find that the R-squareds decline by -0.082 for Olympic firms and -0.054 for non-Olympic firms, representing a difference-in-difference of 0.027 which is significant at the five-percent level. These findings support $P 1$ and $P 2$, that investors use the Olympics as a category for investment.

[Table 3]

Table 4 provides results from the bivariate regression: Model (3). For this specification we report the coefficients. Recall that we expect the coefficient on the Olympic Index to increase and the coefficient on the non-Olympic Index to decrease following the announcement of the winning bid in the build-up to the Olympic games and in the Olympic year. After the Olympic games are played we expect reversals of these signs. Consistent with our predictions, Table 4 shows the betas increasing by 0.052 on the Olympic index from the Pre-Announcement Years to the Middle Years and by 0.099 from the Middle Years to the Olympic Years, while the betas on the non-Olympic index fall during these two periods (-0.013 and -0.121 , respectively). Consistent with a reversal after the Olympics, we find a significant decline in the beta of the Olympic index of -0.042 from the Olympic Years to the Post-Game period; however, we also find an insignificant decline on the nonOlympic beta of -0.012 when we were expecting an increase. Taken together, Table 4 shows that 
beta on the Olympic index increases after the winning bid announcement by 9.2 percent and continues to increase to approximately 27 percent by the year of the Olympic games while the coefficient on the non-Olympic index during this time decreases by approximately 35 percent.

\section{[Table 4]}

Table 5 provides multivariate analysis using the R-Squares from Model $1 \mathrm{a}$ and $1 \mathrm{~b}$ as the dependent variable. In the spirit of Drake et al. (2017), the firm-specific adjusted R-squared for Olympic and non-Olympic stocks obtained for each of the Olympic time periods are regressed on an indicator (Olympic) equal to 1 for Olympic stocks, and indicators for the different Olympic periods: Middle Years, Olympic Years, and the Post-Game Years. We also include controls for firm characteristics (Total assets, ROA, and CFO), and fixed effects (country, year, and industry).

Column (1) of Table 5 combines Middle Years and Olympic Years into one indicator and the base periods are the Pre-Announcement Years and the Post-Game Years. Column (2) separately includes Middle Year, Olympic Year, Post-Game Year indicator variables and the base period is the Pre-Announcement period. The key variables of interest are the interactions between Olympic and the different time periods. In Column (1), the positive and significant coefficient of 0.012 on Olympic * Middle and Olympic Years confirms that Olympic firms have significant increases in comovement relative to non-Olympic firms between the winning bid announcement and the year-end of the Olympic year. Column (2) illustrates that the heightened comovement among Olympic stocks decline in the Post-Game Years as the coefficient on Olympic * Post-Game Years is insignificant while the coefficients on Olympic * Middle Years and Olympic * Olympic Years of 0.021 and 0.014, respectively, are both positive and significant.

In summary, in Tables 2 through 5 , we consistently document that Olympic stocks have increases in comovement after the winning bid is announced and declines in comovements after the 
games are played. These results are consistent with predictions $P 1$ and $P 2$ and suggest that investors use "the Olympics" as a temporary category for investment.

\subsection{Media Stories and Investor Responsiveness}

We predict that that investors use media outlets to identify and buy Olympic stocks and this has comovement and valuation implications. In this section, we directly investigate whether news stories that link the Olympics to a firm result in an investor response for that firm. Such evidence provide corroborative evidence in support of our hypotheses. For ease of exposition and to reduce the number of tests reported, we provide results using comovements calculated from Model 1.

In Table 6 we first report descriptive evidence of the average number of local media mentions containing the words "Olympic" or "Olympics" for both Olympic and non-Olympic stocks for each of the four main Olympic windows. Table 6 shows that while both Olympic and non-Olympic firms have significant increases in Olympic media mentions following the winning bid announcement with the number of articles peaking in the year of the Olympics and then declining afterwards, the increase and decline in articles is more pronounced for Olympic stocks. The difference-in-difference statistics illustrating these trends are all significant at the five-precent level. Figure 5 illustrates the same pattern of the run-up in Olympic media articles in the build-up to the Olympics and then the significant fall after the Games are complete.

[Table 6 and Figure 5]

Table 7 reports abnormal volumes and abnormal return volatility at the winning bid announcement dates, initial Olympic stock classification dates by media, and during the Olympic Games. It illustrates that relative to non-Olympic firms, Olympic firms have significant increases in volume and return volatility on the winning bid announcement days and on days where firms are 
first categorized as an Olympic stocks by the media or social media. These findings support the notion that media attention at the bid announcement as well as firm-specific Olympic media categorizations have significant pricing and valuation effects.

Table 8 provides multivariate analysis to investigate whether comovements increase with media mentions. Note that we have firm-specific R-squareds for both Olympic and non-Olympic firms for four periods. Therefore, each firm has four R-squared observations. Column (1) regresses the comovement measure from Model (1) on Log Media Mentions and control variables. We find a positive and significant coefficient. Column (2) investigates whether there is a stronger relation during the Olympic time period (Middle Years and Olympic Years) and for Olympic firms (Olympic). We find a positive and significant coefficient on the three way interaction (Olympic * Middle Years and Olympic Years * Log Media Mentions), consistent with our expectations.

Together the findings in Tables 7 and 8 support the idea that investors are purchasing Olympic stocks based on the media coverage and the associated Olympic-valuation benefit story, and that media is a key mechanism driving the categorization of Olympic stocks.

[Tables 7 and 8]

\subsection{Fundamental Performance of Olympic Stocks}

The Olympic Games last for two weeks and so tourist flow is likely to be abnormally high in the months surrounding the Olympics. This increased tourist flow suggests that firms in the hospitality industries will exhibit a transitory boost to revenues or cash flows for one or two quarter around the Olympic Games. In contrasts, firms in the construction industry could exhibit more general increases in profits as construction income and revenues are earned over the Middle Years. In this section, we investigate whether the Olympic categorization is justified by changes in 
fundamentals. Specifically, we ask are two questions: Are fundamental benefits of the Olympics sufficiently large to be detectable in the data? And do we observe increases in comovements of fundamentals among Olympic stocks?

\subsubsection{Fundamental benefits of the Olympics}

Table 9 examines whether fundamentals are unusual for Olympic stocks over the Olympic time period. In Table 9, we regress annual return on equity (Column 1) or revenues scaled by equity (Column 2) on indicators for Olympic and non-Olympic stocks and different Olympic time periods (Middle and Olympic Years, and Post-Game Years) plus controls and fixed effects. We use annual data because quarterly or semi-annual data is unavailable in the Pre-Announcement Years for the Sydney 2000, Athens 2004, and Beijing 2008 Olympics. Columns 1 and 2 report the regressions for all Olympic and non-Olympic stocks whereas columns 3 and 4 report the regressions for Olympic sponsors and their non-Olympic matched peers. Prediction P3 predicts that Olympic firms will have positive fundamentals during the Middle Years and/or Olympic Years. However, we do not find evidence that Olympic stocks experience abnormal performance during the run-up to the Olympics or in the Olympic years relative to non-Olympic stocks as the coefficients on Olympic * Middle and Olympic Years are not significant in any of the specifications. It is somewhat surprising that Olympic sponsors do not appear to have unusual profits. The lack of abnormal profitability suggests that there are other motivations driving the sponsorship such as maintaining brand recognition, or nonpecuniary benefits to employees or top executives. In summary, the results in Table 9 do not identify unusual improvements in fundamentals for Olympic firms over the Olympic time period.

\section{[Tables 9]}

It is possible that Olympic stocks experience boosts to earnings and revenues at different points in time during the Olympic time period and the longer windows used in Table 9 are not strong 
enough to isolate any differences in performance. In untabulated analysis using the London and Rio Olympics, where we have interim financial data for the entire Olympic window, we examine whether Olympic stocks relative to non-Olympic stocks have abnormal earnings and revenues in interim periods from the winning bid announcement up until the Olympic year. We find no evidence of abnormal performance for Olympic stocks even for the discrete interim periods in the build-up to the Olympics. In summary, we are unable to reject the null for $P 3$ of no abnormal profitability for Olympic stocks. This lack of results is relevant since it casts doubt on the story presented by the media that Olympic stocks will earn unusual profits in the country hosting the Olympics.

\subsubsection{Comovement of Fundamentals}

Our next test examines whether Olympic stocks have fundamentals that co-move with each other and whether this could explain the increases in comovement that we document. Table 10 provides the following regressions for the Pre-Announcement Years, the Middle and Olympic Years, and the Post-Game Years:

Model 5a: Olympic Fundametal Return $n_{i, t, k}=\alpha_{0}+\beta_{i}$ Olympic Fundamental Index ${ }_{t, k}+\varepsilon_{i, t, k} \quad(5 a)$ Model 5b: Non-Olympic Fundametal Return ${ }_{i, t, k}=\alpha_{0}+\beta_{i}$ Non-Olympic Fundamental Index $x_{t, k}+\varepsilon_{i, t,}(5 b)$

For the analysis in Table 10, we use only the London and Rio Olympics because we have adequate interim financial data. Fundamental Return is either ROE (Column 1 and 3) or revenues scaled by equity (Column 2 and 4). In model 5a, for each Olympic firm $i$, we then regress their quarterly (Rio) or semi-annual (London) return on equity or revenues on an index composed of all Olympic stocks' related measures for the respective periods. We take the R-squareds from these regressions as a measure of fundamental comovement. In model 5b, we do the same for non-Olympic firms but regress their return on equity or revenues on an non-Olympic Fundamental Index. Table 10 reports the regressions of these fundamental comovement measures on indicators for the Middle 
and Olympic Years, Post-Game Years, and controls. Columns 1 and 2 report the results for the London Olympics and Columns 3 and 4 report the results for the Rio Olympics. We find insignificant coefficients on the Olympic * Middle and Olympic Years and the Olympic * Post-Game Years interaction terms for all specifications. Therefore we are unable to reject the null for $P 4$ of no difference in comovements of fundamentals for Olympic stocks.

The findings reported in Table 10 suggests that the increase in stock return comovement after the winning bid announcement is not due to Olympic stocks becoming more sensitive to the same Olympic related macro-economic news that affects underlying fundamentals. In turn, these results support the conjecture that investors are purchasing these stocks based on their "Olympic" characteristic rather than based on their fundamentals. However, caveats to note are that these inferences are based on only two of the five Olympics and we do not have many observations for each firm because financial information is measured only two or four times a year and so our tests are likely to have low power.

\subsection{Categorization by Retail Investors}

The results so far suggest that Olympic firms experience increases in valuations and stock comovements over the Olympic period; the comovements effects are stronger for firms with greater media attention; but the fundamentals of Olympic firms are not unusual relative to non-Olympic firms over the Olympic period. To build on our hypothesis that the greater media attention on Olympic stocks is the cause of the valuation effects that we observe, we next investigate retail ownership. If retail investors are less sophisticated than institutional investors, then they are more likely to make investment decisions based on factors other than fundamentals. If this is the case, then retail investors are more likely to buy stocks based on investment stories provided by media outlets. 
Table 11, Panel A reports the comovement of Olympic stocks from Table 2 separately for those stocks with greater than 50 percent and those stocks with less than 50 percent retail investor ownership. We find stronger results for firms with high retail investor bases, with significant increases in comovement between the Pre-Announcement Years up until the Olympic Years games and significant reversals after the Olympic games are played. Panel B confirms these inferences using multivariate regression analysis. The results in Table 11 highlight that increases in comovement for Olympic stocks is concentrated among firms with high retail investor bases.

[Table 11]

5. Additional Analyses: Application to Other Event-Based Settings

A key take away from the main analyses is that event-based media or social-media hype over certain stocks combined with a significant retail investor base will lead to event-based categorizations that will have implications for stock valuations and risk. In this section we explore whether our results are applicable to other settings.

\subsection{Olympics in Japan}

Our results are based on five past summer Olympics. Do our findings extend to Japan, the country that won the bid to hold the 2020 Olympics? Figure 6 provides a similar graph as Figure 4 for stocks we identified in Japanese media as likely to benefit from the Olympics. Note that Japan offers an interesting setting since Japan had to defer the games due to concerns over the spread of the coronavirus. Figure 6 illustrates a clear and sharp rise in the comovement of Japanese Olympic stocks following the bid announcement. The comovement peaks during the 2016 Rio Olympics. The bad news regarding the pandemic and Olympic postponement appears to cause temporary 
declines in comovements for Olympic stocks in March 2020. However, after March 2020, comovement increases as the probability that the games would be held in August of 2021 increased. $^{8}$

[Figure 6]

\subsection{Stay-at-Home and Meme Stocks}

Figure 7 investigates stocks that are classified by analysts and the media as Stay-at-Home. In 2020, many governments attempted to slow the spread of the coronavirus by mandating lockdowns which encouraged people to limit their interactions with others and work from home. Stay-at-Home stocks were promoted as stocks that were likely to benefit from lockdowns. Analysts and the media first began creating lists of Stay-at-Home stocks in late February 2020 (see notes to Figure 7 for more details of the sample selection). Figure 7 provides comovements changes, media mentions, and abnormal stock returns. The comovement of the 46 Stay-at-Home stocks, relative to their matched peers, began to increase once the second Covid-19 wave hit in July, 2020. This was the time when U.S. states began reversing their reopening plans and is likely to be the point where the public realized that Covid shutdowns were going to continue at least until the end of the year. The comovement of Stay-at-Home stocks has continued to remain elevated and recently peaked at the start of the $3^{\text {rd }}$ Covid wave. Media mentions also peaked at the time of the $3^{\text {rd }}$ wave. These stocks have also earned abnormal returns relative to their matched peers.

Figure 8 provides our analysis of Meme stocks. These are a group of stocks that went viral among retail investors on the Reddit-based Wall Street Bets social media forum largely based on the

\footnotetext{
${ }^{8} \mathrm{We}$ also examined comovement for 43 Olympic stocks that we identify for the 1996 Atlanta Olympics. We do not view the Atlanta Olympics as a powerful setting to investigate comovements effects due to stock categorization because (i) retail investors were less able to trade in and out of stocks due to higher fees and the lack of cheap brokerage options over the Olympic time period (Atlanta's winning bid was announced September 18, 1990); (ii) the media was not hyping Olympic stocks as a category for investment; and (iii) fewer people in the U.S. had access to the internet during the Olympic time period and there were no social media cites were retail investors could communicate with each other about Olympic stocks. Consistent with our expectations, in untabulated results, we do not observe evidence that the Atlanta Olympics were used as a category of investment. Thus, investor categorization is likely to be a more pronounced phenomenon in a post-internet world.
} 
potential to create short-squeezes. We believe that the Meme stocks are a powerful setting to examine the generalizability of our main findings since by definition the Meme stock categorization was driven by social media and retail investors. Figure 8 illustrates a substantial increase in comovement for the 44 Meme stocks relative to matched peers in January of 2021 during the first Meme wave where the return comovements of these unrelated stocks went from near zero to almost 20 percent within a month. The comovement of these stocks pulled back after the Meme rally lost considerable momentum when the leading retail trading platform Robinhood announced a controversial trading halt on all of the leading Meme stocks, only to increase after the start of the second Meme wave in late February 2021. Additionally, it appears that comovement of Meme stocks continues to stay elevated as the third Meme wave transpires. Note that because of the Meme movement, all firms with high-short interest have started to comove together even though only a portion have been deemed as Meme stocks. Therefore, the fact that our non-Meme matched firms also experience a significant increase in comovements is not surprising since we use short-interest in our matching criteria. We also observe significant positive abnormal returns for Meme stocks consistent with the objective of squeezing the shorts.

In summary, the Stay-at-Home and Meme results support our contention that media hype and retail investor attention are key mechanisms for driving the investor categorization, and in turn rising comovements, as both of these forces were at play in the Stay-at-Home and Meme stock movements. These results are descriptive, but are suggestive that our findings for the Olympics are likely to hold in other event-based settings.

[ Figures 7 and 8] 


\section{Conclusion}

The purpose of this study is to examine whether investors use the Olympics as a category for investment after the winning Olympic bid is announced. We hypothesize that the combination of good fundamental news about the Olympics along with the strong media attention on the Olympics, will increase investor recognition of stocks that potentially benefit from the Olympics. Based on theories of style investing we make several predictions. First, we predict that the heightened media attention on the Olympics will encourage retail investors to identify Olympic stocks as a category for investment. Second, based on categorization theories, we predict that after the Olympics are announced, the stock returns for Olympic firms will covary more strongly with each other, and be driven more by market-wide movements. Third, we predict that the impact of the Olympics on fundamentals will be small and comovement of fundamentals not large enough to justify the changes in comovements in stock returns that we observe.

We examine the past five summer Olympic hosting countries in our main analyses. First, we find that returns of Olympic stocks are up to 60 percent higher than those of non-Olympic stocks in the run-up to the Olympic Games, but approximately half of these higher returns reverse prior to the start of the Games. Second, we show that the covariation of returns increases among Olympic stocks after the winning bid is announced and increases again in the period immediately before the games are played and declines afterwards. We also find that Olympic stocks have significant increases in comovements with the market during the Olympic time period. Third, we show that Olympic firms do not appear to generate abnormal cumulative profits or revenues over the Olympic period. Thus the valuation effects that we document do not appear to be driven by changes in fundamentals or strong comovements in underlying fundamentals. 
The study's findings illustrate that media or social-media attention of certain stocks combined with significant retail attention can lead to event-based investor categorizations. Consistent with this premise, the results extend and generalize to other settings where the media or social media sell a categorization story to retail investors. We provide preliminary evidence showing similar increases in comovement for the upcoming Tokyo Olympic stocks, and for the Stay-at-Home and Meme stocks. Our results highlight that firms can benefit from these types of categorization since we observe positive stock returns after the categorization begins. We leave it to future research to identify future events and settings where these forces will continue to impact firm valuations. 


\section{REFERENCES}

Antweiler, W., and M. Frank. 2004. Is all that talk just noise? The information content of internet stock message boards. Journal of Finance 59 (3): 1259-1294.

Barber, B., and T. Odean. 2008. All that glitters: The effect of attention and news on the buying behavior of individual and institutional investors. Review of Financial Studies 21 (2): 785-818.

Barberis, N., A. Shleifer, and R. Vishny. 1998. A model of investor sentiment. Journal of Financial Economics 49 (3): 307-343.

— and - 2003. Style investing. Journal of Financial Economics 68 (2): 161-199.

$\longrightarrow,-$, and J. Wurgler. 2005. Comovement. Journal of Financial Economics 75 (2): 283-317.

Barclay, J. 2009. Predicting the costs and benefits of mega-sporting events: Misjudgement of Olympic proportions? Economic Affairs 29 (2): 62-66.

Beaver, W. 1968. The information content of annual earnings announcements. Journal of Accounting Research: 67-92.

Bloomfield, R. 2002. The incomplete revelation hypothesis and financial reporting. Accounting Horizons 16 (3): 233-243.

Briz, G., and J. Lott. 2011. The effect of macroeconomic news on stock returns: New evidence from newspaper coverage. Journal of Banking \& Finance 35 (11): 2791-2800.

Bushee, B., J. Core, W. Guay, and S. Hamm. 2010. The role of the business press as an information intermediary. Journal of Accounting Research 48 (1): 1-19.

Chan, K., and A. Hameed. 2006. Stock price synchronicity and analyst coverage in emerging markets. Journal of Financial Economics 80 (1): 115-147.

Crawford, S., D. Roulstone, and E. So. 2012. Analyst initiations of coverage and stock return synchronicity. The Accounting Review 87 (5): 1527-1553.

Cooper, M., O. Dimitrov, and R. Rau. 2001. A rose.com by any other name. Journal of Finance 56 (6): 23712388.

Drake, M., J. Jennings, D. Roulstone, and J. Thornock. 2017. The comovement of investor attention. Management Science 63 (9): 2847-2867.

Durnev, A., R. Morck, and B. Yeung, 2004. Value-enhancing capital budgeting and firm-specific stock return variation. Journal of Finance 59: 65-105.

Dyck, A., A. Morse, and L. Zingales. 2010. Who blows the whistle on corporate fraud? Journal of Finance 65 (6): 2213-2253.

Engelberg, J., and C. Parsons. 2011. The causal impact of media in financial markets. Journal of Finance 66 (1): 67-97. 


\section{REFERENCES (CONT.)}

Hameed, A., R. Morck, J. Shen, and B. Yueng. 2015. Information, analysts, and stock return comovement. Review of Financial Studies 28 (11): 3153-3187.

Hirshleifer, D., and S.H. Teoh. 2003. Limited attention, information disclosure, and financial reporting. Journal of Accounting \& Economics 36 (1-3): 337-386.

Kalay, A. 2015. Investor sophistication and disclosure clienteles. Review of Accounting Studies 20 (2): 9761011.

Kumar, A. and C. Lee. 2006. Retail investor sentiment and return comovements. Journal of Finance 61 (5): 2451-2486.

— J. Page, and O. Spalt. 2013. Investor sentiment and return comovements: Evidence from stock splits and headquarters changes. Review of Finance 17 (3): 921-953.

Lawrence, A., J. Ryans, E. Sun, and N. Laptev. 2018. Earnings announcement promotions: A Yahoo Finance field experiment. Journal of Accounting and Economics 66 (2-3): 399-414.

Lawtime. 2010. Investment Roadmap of Beijing Olympic-Theme Stocks. December 20, 2010.

Lee, C., A. Shleifer, and R. Thaler. 1991. Investor sentiment and the closed-end fund puzzle. Journal of Finance 46 (1): 75-109.

Lehavy, R., and R. Sloan. 2008. Investor recognition and stock returns. Review of Accounting Studies 13 (23): $327-361$.

Li, E., K. Ramesh, and M. Shen. 2011. The role of newswires in screening and disseminating value-relevant information in periodic SEC reports. The Accounting Review 86 (2): 669-701.

Li, J. and J. Yu. 2012. Investor attention, psychological anchors, and stock return predictability. Journal of Financial Economics 104 (2): 401-419.

Merton, R. 1987. A simple model of capital market equilibrium with incomplete information. Journal of Finance 42 (3): 483-510.

Miller, G. 2006. The press as a watchdog for accounting fraud. Journal of Accounting Research 44 (5): 10011033.

Morck, R., B. Yeung, and W. Yu. 2000. The information content of stock markets: Why do emerging markets have synchronous stock price movements? Journal of Financial Economics 58 (1-2): 215-260.

Muslu, V., M. Rebello, and Y. Xu. 2014. Sell-side analyst research and stock comovement. Journal of Accounting Research 52 (4): 911-954.

Nielsen. 2008. Beijing Olympics Draw Largest Ever Global TV Audience. September 5, 2008.

Nikkei Asian Review. 2019. Tokyo Olympics Budget Swells To \$12BN A Year Before Games. July 24, 2019. 


\section{REFERENCES (CONT.)}

Owen. 2005. Estimating the cost and benefit of hosting the Olympic Games. The Industrial Geographer 3 (1): $1-18$.

Pirinsky, C., and Q. Wang. 2006. Does corporate headquarters location matter for stock returns? Journal of Finance 4 (August): 1991-2015.

Roll, R., 1988. R2. Journal of Finance 43 (3): 541-566.

Reuters. 2017. Rio 2016 Price Tag Rises To \$13.2 Billion. June 14, 2017.

Solomon, D., E. Soltes, and D. Sosyura. 2014. Winners in the spotlight: Media coverage of fund holdings as a driver of flows. Journal of Financial Economics 113 (1): 53-72.

Tetlock, P. 2011. All the news that's fit to reprint: Do investors react to stale information? Review of Financial Studies 24 (5): 1481-1512.

Vijh, A. 1994. S\&P trading strategies and stock betas. Review of Financial Studies 7 (1): 215-251.

Whitson, D., and J. Horne. 2006. Underestimated costs and overestimated benefits? Comparing the outcomes of sports mega-events in Canada and Japan. The Sociological Review 54 (Supplement 2): 73-89. 


\section{APPENDIX A}

Examples of Olympic Stocks

\begin{tabular}{|c|c|c|c|c|}
\hline $\begin{array}{l}\text { Factset } \\
\text { Identifier }\end{array}$ & Country & Firm Name & Industry Name & $\begin{array}{l}\text { Reason for Classification as an } \\
\text { Olympic Stock }\end{array}$ \\
\hline BDG0N4 & Australia & $\begin{array}{l}\text { Event Hospitality \& } \\
\text { Entertainment }\end{array}$ & Movies/Entertainment & $\begin{array}{l}\text { Provides hotels and resort services } \\
\text { related to the Olympics }\end{array}$ \\
\hline 694943 & Australia & $\begin{array}{l}\text { Seven West Media } \\
\text { Limited }\end{array}$ & Broadcasting & $\begin{array}{l}\text { Provides television broadcasting } \\
\text { services related to the Olympics }\end{array}$ \\
\hline 606558 & Australia & $\begin{array}{l}\text { Australia and New } \\
\text { Zealand Banking Group }\end{array}$ & Major Banks & $\begin{array}{l}\text { Provides lending services to firms } \\
\text { benefiting from the Olympics }\end{array}$ \\
\hline 651200 & Australia & Lendlease Group & $\begin{array}{l}\text { Real Estate } \\
\text { Development }\end{array}$ & $\begin{array}{l}\text { Property and infrastructure } \\
\text { development for the Olympics }\end{array}$ \\
\hline BX17Q1 & Australia & CIMIC Group Limited & $\begin{array}{l}\text { Engineering \& } \\
\text { Construction }\end{array}$ & $\begin{array}{l}\text { Construction projects for the } \\
\text { Olympics }\end{array}$ \\
\hline 614469 & Australia & BHP Group Ltd & $\begin{array}{l}\text { Other } \\
\text { Metals/Minerals }\end{array}$ & $\begin{array}{l}\text { Production of building materials } \\
\text { for the Olympics }\end{array}$ \\
\hline 402494 & Greece & AEGEK & $\begin{array}{l}\text { Engineering \& } \\
\text { Construction }\end{array}$ & $\begin{array}{l}\text { Construction and real estate } \\
\text { development for the Olympics }\end{array}$ \\
\hline 505160 & Greece & $\begin{array}{l}\text { Hellenic } \\
\text { Telecommunications } \\
\text { Organization }\end{array}$ & $\begin{array}{l}\text { Specialty } \\
\text { Telecommunications }\end{array}$ & $\begin{array}{l}\text { Fixed-line television and mobile } \\
\text { telecommunication services } \\
\text { related to the Olympics }\end{array}$ \\
\hline 442155 & Greece & $\begin{array}{l}\text { Heracles General } \\
\text { Cement Company }\end{array}$ & $\begin{array}{l}\text { Construction } \\
\text { Materials }\end{array}$ & $\begin{array}{l}\text { Production of cement, concrete, } \\
\text { and aggregates for the Olympics } \\
\text { infrastructure }\end{array}$ \\
\hline 577717 & Greece & Attica Publications & $\begin{array}{l}\text { Publishing: } \\
\text { Newspapers }\end{array}$ & $\begin{array}{l}\text { Publication and distribution of } \\
\text { magazines that will benefit from } \\
\text { Olympic advertising }\end{array}$ \\
\hline B1ZBHG & Greece & Aegean Airlines & Airlines & $\begin{array}{l}\text { Provision of air transport services } \\
\text { for passengers supporting Olympic } \\
\text { tourism }\end{array}$ \\
\hline 465873 & Greece & DROMEAS & Home Furnishings & $\begin{array}{l}\text { Office furniture, kitchen and home } \\
\text { furniture, and die-casted aluminum } \\
\text { equipment for the Olympics }\end{array}$ \\
\hline 000402 & China & $\begin{array}{l}\text { Financial Street } \\
\text { Holdings }\end{array}$ & $\begin{array}{l}\text { Real Estate } \\
\text { Development }\end{array}$ & $\begin{array}{l}\text { Owns commercial rental properties } \\
\text { in Beijing that will benefit from } \\
\text { Olympics }\end{array}$ \\
\hline 600859 & China & Wangfujing Group & Department Stores & $\begin{array}{l}\text { Main retail commercial company } \\
\text { in Beijing that will benefit from } \\
\text { Olympic tourism }\end{array}$ \\
\hline 000969 & China & $\begin{array}{l}\text { Advanced Technology } \\
\& \text { Materials }\end{array}$ & Steel & $\begin{array}{l}\text { Provides construction materials to } \\
\text { Olympic venues }\end{array}$ \\
\hline 000802 & China & $\begin{array}{l}\text { Beijing Jingxi Culture } \\
\text { and Tourism }\end{array}$ & $\begin{array}{l}\text { Other Consumer } \\
\text { Services }\end{array}$ & $\begin{array}{l}\text { Owns main tourism resources in } \\
\text { Beijing that will benefit from } \\
\text { Olympic tourism }\end{array}$ \\
\hline 000860 & China & $\begin{array}{l}\text { Beijing Shunxin } \\
\text { Agriculture }\end{array}$ & $\begin{array}{l}\text { Agricultural } \\
\text { Commodities/Milling }\end{array}$ & $\begin{array}{l}\text { Main provider of meat and } \\
\text { vegetables in Beijing that will } \\
\text { support Olympic tourism }\end{array}$ \\
\hline 000839 & China & $\begin{array}{l}\text { CITIC Guoan } \\
\text { Information Industry }\end{array}$ & $\begin{array}{l}\text { Telecommunications } \\
\text { Equipment }\end{array}$ & $\begin{array}{l}\text { Information transmission, cable } \\
\text { television and mobile } \\
\text { communications for the Olympics }\end{array}$ \\
\hline
\end{tabular}




\section{APPENDIX A (continued)}

Examples of Olympic Stocks

\begin{tabular}{|c|c|c|c|c|}
\hline $\begin{array}{l}\text { Factset } \\
\text { Identifier }\end{array}$ & Country & Firm Name & Industry Name & $\begin{array}{l}\text { Reason for Classification as an } \\
\text { Olympic Stock }\end{array}$ \\
\hline 009616 & UK & Balfour Beatty & $\begin{array}{l}\text { Engineering \& } \\
\text { Construction }\end{array}$ & $\begin{array}{l}\text { Construction projects for the } \\
\text { Olympics }\end{array}$ \\
\hline 310221 & UK & Telford Homes Plc & Homebuilding & $\begin{array}{l}\text { East London housebuilder- } \\
\text { Olympics expected to bring } \\
\text { regeneration }\end{array}$ \\
\hline 006532 & UK & Avesco Group & $\begin{array}{l}\text { Miscellaneous } \\
\text { Commercial Services }\end{array}$ & $\begin{array}{l}\text { Leases audio visual equipment, } \\
\text { including large-scale displays } \\
\text { and audio equipment, which was } \\
\text { expected to be employed at } \\
\text { Olympic venues }\end{array}$ \\
\hline B460T3 & UK & Tandem Group & Recreational Products & $\begin{array}{l}\text { Licensed to sell branded } \\
\text { products (e.g., Olympic } \\
\text { bicycles) }\end{array}$ \\
\hline B7KR2P & UK & easyJet & Airlines & $\begin{array}{l}\text { Transportation services for the } \\
\text { Olympics }\end{array}$ \\
\hline B1YPC3 & UK & Fuller, Smith \& Turner & Beverages: Alcoholic & $\begin{array}{l}\text { Pubs owner and brewer of } \\
\text { London Pride which will } \\
\text { directly benefit from Olympic } \\
\text { tourism }\end{array}$ \\
\hline B1VYRW & Brazil & $\begin{array}{l}\text { CR2 Empreendimentos } \\
\text { Imobiliarios }\end{array}$ & Real Estate Development & $\begin{array}{l}\text { Development and sale of real } \\
\text { estate properties that will benefit } \\
\text { from the Olympics }\end{array}$ \\
\hline 283554 & Brazil & $\begin{array}{l}\text { Santos Brasil } \\
\text { Participacoes SA }\end{array}$ & Other Transportation & $\begin{array}{l}\text { Provision of logistics services } \\
\text { for the Olympics }\end{array}$ \\
\hline 219628 & Brazil & Vale & Steel & $\begin{array}{l}\text { Production and exportation of } \\
\text { iron ore, pellets, manganese, and } \\
\text { iron alloys for the Olympics }\end{array}$ \\
\hline BG7ZWY & Brazil & Ambev SA & Beverages: Alcoholic & $\begin{array}{l}\text { Production, distribution, and } \\
\text { sale of beverages for the } \\
\text { Olympics }\end{array}$ \\
\hline $\mathrm{B} 23 \mathrm{CS} 0$ & Brazil & $\begin{array}{l}\text { BHG SA - Brazil } \\
\text { Hospitality Group }\end{array}$ & Hotels/Resorts/Cruiselines & $\begin{array}{l}\text { Hotel services related to the } \\
\text { Olympics }\end{array}$ \\
\hline 247961 & Brazil & Gafisa SA & Homebuilding & $\begin{array}{l}\text { Construction, development and } \\
\text { selling of residential properties } \\
\text { which will benefit from } \\
\text { Olympic tourism }\end{array}$ \\
\hline
\end{tabular}

Appendix A provides examples of firms designated as Olympic stocks for the five summer Olympics included in our main sample: Australia (Sydney, 2000); Greece (Athens, 2004); China (Beijing, 2008); United Kingdom (London, 2012); and Brazil (Rio de Janeiro, 2016). The main sample consists of 213 Olympic stocks that were publicly traded as of the Olympic winning bid announcement. For the Sydney 2000 Olympics, we used Factiva as the news source to identify stocks that will benefit from the Olympics. For the Athens 2004 Olympics, we used websites of local media sources such as https://www.kathimerini.gr/, https://www.tanea.gr/ and https://www.naftemporiki.gr/. For the Beijing 2008 Olympics, we used social media sites Sina.com.cn and jrj.com.cn as they made lists and categorized Olympic stocks. For the London 2012 Olympics, we searched all news articles from the Financial Times for mentions of stocks expected to be involved in or benefit from the London Olympics. For the Rio 2016 Olympics, we used Bloomberg and local media sources such as https://www.infomoney.com.br/ for mentions of stocks that will benefit from the Olympics. The 213 Olympic stocks also include all of the official sponsors and partners for each country that were publicly traded as of the Olympic winning bid announcement. 


\section{APPENDIX B}

Variable Definitions

\begin{tabular}{|c|c|}
\hline Variable & Definition \\
\hline Abnormal Volume & $\begin{array}{l}\text { The average daily volume at the event period (day }-1 \text {, day }+1) \text { minus the average volume in } \\
\text { the non-event period divided by standard deviation of volume in the non-event period. The } \\
\text { event periods are either the Olympics announcement date, the initial Olympic stock } \\
\text { classification date by the media, or the Olympic game dates. The non-event or estimation } \\
\text { period is defined as the period from } 130 \text { to } 10 \text { days prior to the event and from } 10 \text { to } 130 \\
\text { days after the event; }\end{array}$ \\
\hline Assets_E & Total annual assets divided by average annual book value of equity as of the fiscal year-end; \\
\hline Book-to-Market & $\begin{array}{l}\text { Book value of equity as of the fiscal year-end scaled by the market value of equity as of the } \\
\text { fiscal year-end; }\end{array}$ \\
\hline Comovement & $\begin{array}{l}\text { Average adjusted } \mathrm{R}^{2} \text { for each period (Pre-Announcement Years, Middle Years, Olympic } \\
\text { Years, and Post-Game Years) of Olympic (non-Olympic) firm-specific regressions of daily } \\
\text { returns on an Olympic (non-Olympic) index (Models 1a and } 1 \mathrm{~b} \text { ), using daily returns over the } \\
\text { preceding year. The daily Olympic (non-Olympic) stock index returns are the average of the } \\
\text { daily returns of all Olympic (non-Olympic) firms excluding firm } i \text {; }\end{array}$ \\
\hline $\begin{array}{l}\text { Comovement of } \\
\text { Fundamentals }\end{array}$ & $\begin{array}{l}\text { Average adjusted } \mathrm{R}^{2} \text { for each period (Pre-Announcement Years, Middle and Olympic Years, } \\
\text { and Post-Game Years) of Olympic (non-Olympic) firm-specific regressions of quarterly or } \\
\text { semi-annual fundamental returns on an Olympic (non-Olympic) index of fundamental } \\
\text { returns (Models 5a and 5b), using quarterly or semi-annual returns over the period. The } \\
\text { Olympic (non-Olympic) stock index of fundamental returns are the average of the quarterly } \\
\text { or semi-annual returns of all Olympic (non-Olympic) firms excluding firm } i \text {; }\end{array}$ \\
\hline $\begin{array}{l}\text { Cumulative Returns } \\
\text { from the Bid } \\
\text { Announcement Year to }\end{array}$ & $\begin{array}{l}\text { Calculated as the monthly compounded returns, starting in January of the year of the } \\
\text { Olympics announcement (see Table } 1 \text { Panel A for announcement dates) and ending at the } \\
\text { respective period month-end; }\end{array}$ \\
\hline
\end{tabular}

the Respective Month-

End after the Bid

Announcement (\%)

CFO

Earnings-to-Price

Fundamental Return

Insider Investors

Institutional Investors

Log Media Mentions

Log of Total Assets

Market Cap

Market Index Returns

(\%)

Annual cash flows from operations scaled by average annual assets;

Annual net income scaled by the market value of equity as of the fiscal year-end;

The individual firm's quarterly or semi-annual ROE or Revenue_E;

The portion of total shares outstanding held by insiders as of the fiscal year-end;

The percentage of total shares outstanding held by institutions as of the fiscal year-end;

The natural logarithm of (1+Media Mentions);

The natural logarithm of total assets as of the fiscal year-end;

Market capitalization in USD as of the fiscal year-end;

The daily market index returns for each period (Pre-Announcement years, Middle Years, Olympic Years, and Post-Game Years), calculated as the daily returns of the Olympic country's respective market index which is one of the following: ASX All Ordinaries (Sydney 2000), ATHEX Composite (Athens 2004), Shanghai A Share Shanghai A Share or Shenzhen Index (Beijing 2008), FTSE All Shares or AIM index (London 2012), and BOVESPA (Rio 2016);

Media Mentions Media mentions for each firm, calculated as the number of Factiva media articles from local news sources that include the words "Olympic" or "Olympics" during the calendar year;

Middle Years

$=1$ for the seven years after the Olympics announcement and 0 otherwise;

Middle and Olympic $=1$ for the seven years after the Olympics announcement and the year of the Olympics, and 0 for the three years prior to the announcement and for the three years after the announcement; 


\section{APPENDIX B (CONT.)}

\begin{tabular}{|c|c|}
\hline Variable & Definition \\
\hline $\begin{array}{l}\text { Non-Olympic Index } \\
(\%)\end{array}$ & $\begin{array}{l}\text { The daily non-Olympic stock index returns, calculated as the average of the daily returns } \\
\text { of all non-Olympic firms excluding firm } i \text { for each period (Pre-Announcement Years, } \\
\text { Middle Years, Olympic Years, and Post-Game Years); }\end{array}$ \\
\hline Olympic & $=1$ if the firm is classified as Olympic and 0 otherwise; \\
\hline $\begin{array}{l}\text { Olympic Fundamental } \\
\text { Index }\end{array}$ & $\begin{array}{l}\text { The average quarterly (semi-annual) ROE, or Revenue_E of all Olympic firms excluding } \\
\text { firm } i \text { for each period (Pre-Announcement Years, Middle and Olympic Years, and Post- } \\
\text { Game Years); }\end{array}$ \\
\hline Olympic Index $(\%)$ & $\begin{array}{l}\text { The daily Olympic stock index returns, calculated as the average of the daily returns of all } \\
\text { Olympic firms excluding firm } i \text { for each period (Pre-Announcement Years, Middle Years, } \\
\text { Olympic Years, and Post-Game Years); }\end{array}$ \\
\hline $\begin{array}{l}\text { Olympic Stock Return } \\
(\%)\end{array}$ & $\begin{array}{l}\text { Daily stock return of individual Olympic stocks for each period (Pre-Announcement, } \\
\text { Middle Years, Olympic Years, and Post-Game Years); }\end{array}$ \\
\hline Olympic Years & $=1$ for the year of the Olympic Games and 0 otherwise; \\
\hline Post-Game Years & $=1$ for the three years after the Olympic Games and 0 otherwise; \\
\hline $\begin{array}{l}\text { Pre-Announcement } \\
\text { Years }\end{array}$ & $=1$ for the three years prior to the announcement of the Olympics and 0 otherwise; \\
\hline $\mathrm{R}^{2}$ REVENUE_E & $\begin{array}{l}\text { The adjusted } \mathrm{R}^{2} \text { coefficients from firm-specific regressions of quarterly or semi-annual } \\
\text { Revenue_E on an Olympic index of quarterly or semi-annual Revenue_E for each period } \\
\text { (Pre-Announcement Years, Middle and Olympic Years, and Post-Game Years); }\end{array}$ \\
\hline $\mathrm{R}^{2}{ }_{\mathrm{ROE}}$ & $\begin{array}{l}\text { The adjusted } \mathrm{R}^{2} \text { coefficients from firm-specific regressions of quarterly or semi-annual } \\
\text { ROE on an Olympic index of quarterly or semi-annual ROE for each period (Pre- } \\
\text { Announcement Years, Middle and Olympic Years, and Post-Game Years); }\end{array}$ \\
\hline Retail Investors & $\begin{array}{l}\text { The remaining shares outstanding after excluding institutional investor ownership and } \\
\text { insider ownership from FactSet. However, if the sum of institutional and insider ownership } \\
\text { exceeds } 100 \text { percent, due to the effects of significant short sale positions on the stock, then } \\
\text { we assign the retail investor as } 0 \text { percent. Additionally, for the earlier Olympics in the } \\
\text { sample, if the ownership data is missing in order to save observations we assume that the } \\
\text { ownership data is the same as of the earliest fiscal year-end available in FactSet; }\end{array}$ \\
\hline Revenue & $\begin{array}{l}\text { Computed as revenues scaled by average assets for each period (Pre-Announcement } \\
\text { Years, Middle and Olympic Years, and Post-Game Years); }\end{array}$ \\
\hline Revenue_E & $\begin{array}{l}\text { Computed as revenues scaled by average book value of equity for each period (Pre- } \\
\text { Announcement Years, Middle and Olympic Years, and Post-Game Years); }\end{array}$ \\
\hline ROA & Computed as annual net income scaled by average assets; \\
\hline ROE & $\begin{array}{l}\text { Computed as annual net income scaled by average book value of equity for each period } \\
\text { (Pre-Announcement Years, Middle and Olympic Years, and Post-Game Years); }\end{array}$ \\
\hline Synchronicity & $\begin{array}{l}\text { Twelve-month rolling moving average of the percentage of Olympic stocks that are up, } \\
\text { down or unchanged for each day. The fraction of stocks that move in the same direction } \\
\text { in country } \mathrm{k} \text { are calculated as: Synchronicity } y_{t, k}=1 / T \sum_{t} \max \left[\eta_{k t}^{u p}, \eta_{k t}^{\text {down }}, \eta_{k t}^{\text {same }}\right] /\left[\eta_{k t}{ }^{u p}+\right. \\
\left.\eta_{k t}{ }^{\text {down }}+\eta_{k t} \text { same }\right] . \eta_{k t}^{u p} \text { is the number of Olympic (non-Olympic) stocks whose prices rise in } \\
\text { period } t \text { in country } k, \eta_{k t} \text { down is the number of Olympic (non-Olympic) stocks whose prices } \\
\text { fall, and } \eta_{k t} \text { same is the number of Olympic (non-Olympic) stocks whose prices stay the } \\
\text { same, and } T \text { is the number of periods used (Morck et al., 2000); }\end{array}$ \\
\hline Total Assets & Total annual assets in USD reported as of the fiscal year-end; and, \\
\hline U-statistic & $\begin{array}{l}\text { Calculated by dividing the squared residual returns by the variance of the residual returns } \\
\text { following Beaver (1968). We estimate the market model with daily stock returns in the } \\
\text { non-event or estimation period, obtain estimates of the intercept and slope coefficients, } a_{i} \\
\text { and } b_{i} \text {, and calculate the residual returns and variance. }\end{array}$ \\
\hline
\end{tabular}




\section{FIGURE 1}

The Morgan Stanley Composite Index (MSCI) World Index from 1988 to 2020

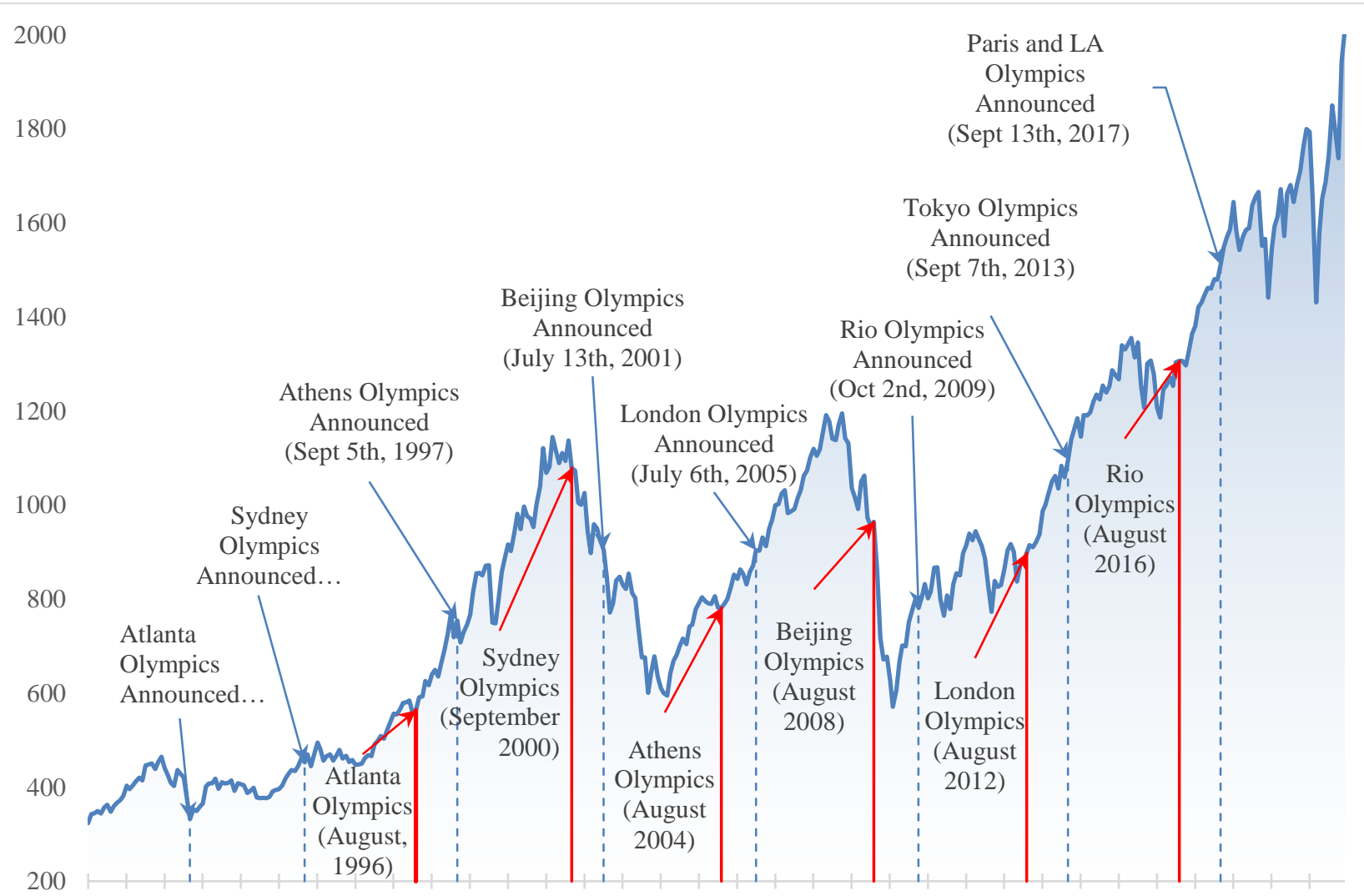

888990919293949596979899000102030405060708091011121314151617181920

Figure 1 presents the MSCI World Index, which captures large and mid-cap equity performance across 23 developed markets countries, from January $1^{\text {st }}, 1988$ until December $31^{\text {st }}, 2020$. We include the winning bid announcement dates for nine summer Olympics (Atlanta, Sydney, Athens, Beijing, London, Rio, Tokyo, Paris, and Los Angeles) and the date of the games for the six most recent games (Atlanta August, 1996; Sydney August, 2000; Athens August, 2004; Beijing August, 2008; London July/August, 2012; and Rio August, 2016). The following five summer Olympics are included in our main sample: Australia (Sydney, 2000); Greece (Athens, 2004); China (Beijing, 2008); United Kingdom (London, 2012); and Brazil (Rio de Janeiro, 2016). 


\section{FIGURE 1}

Cumulative Returns for Key Olympic Games Event Windows

Panel A: Host country stock returns at the announcement of the winning bid for the Olympics

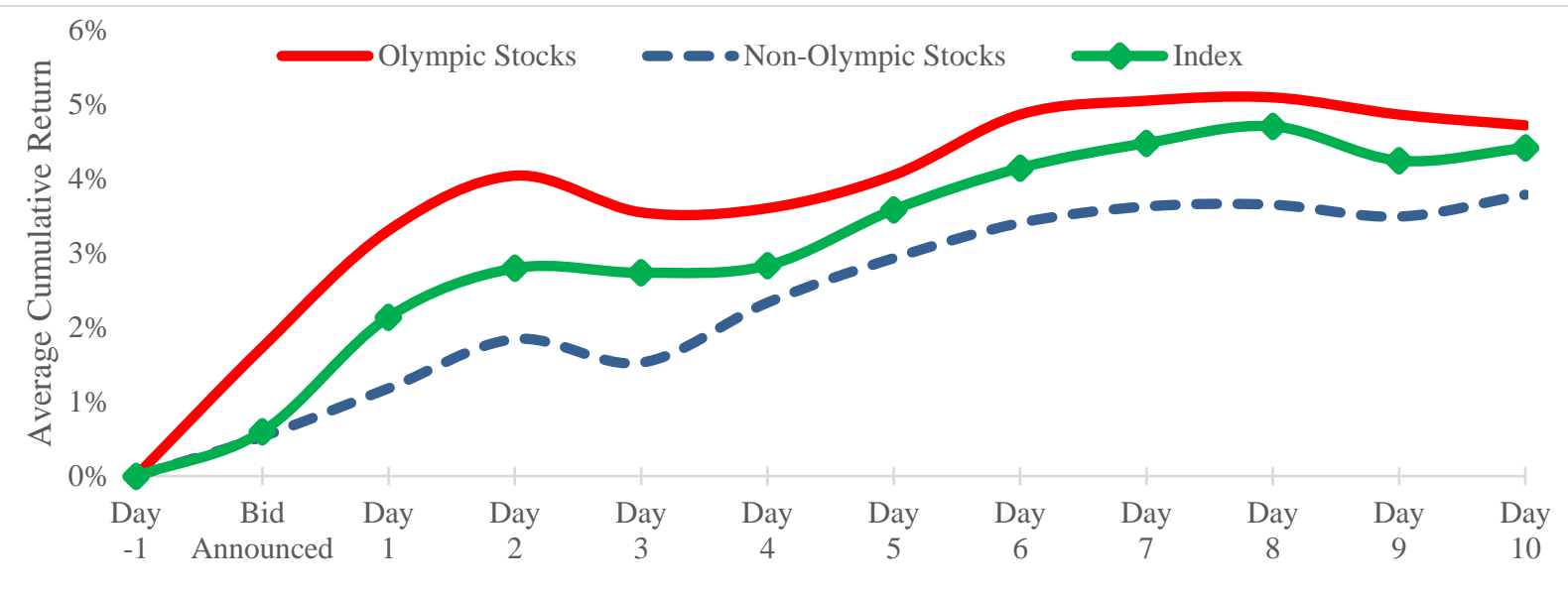

Panel B: Host country stock returns during the Olympic games

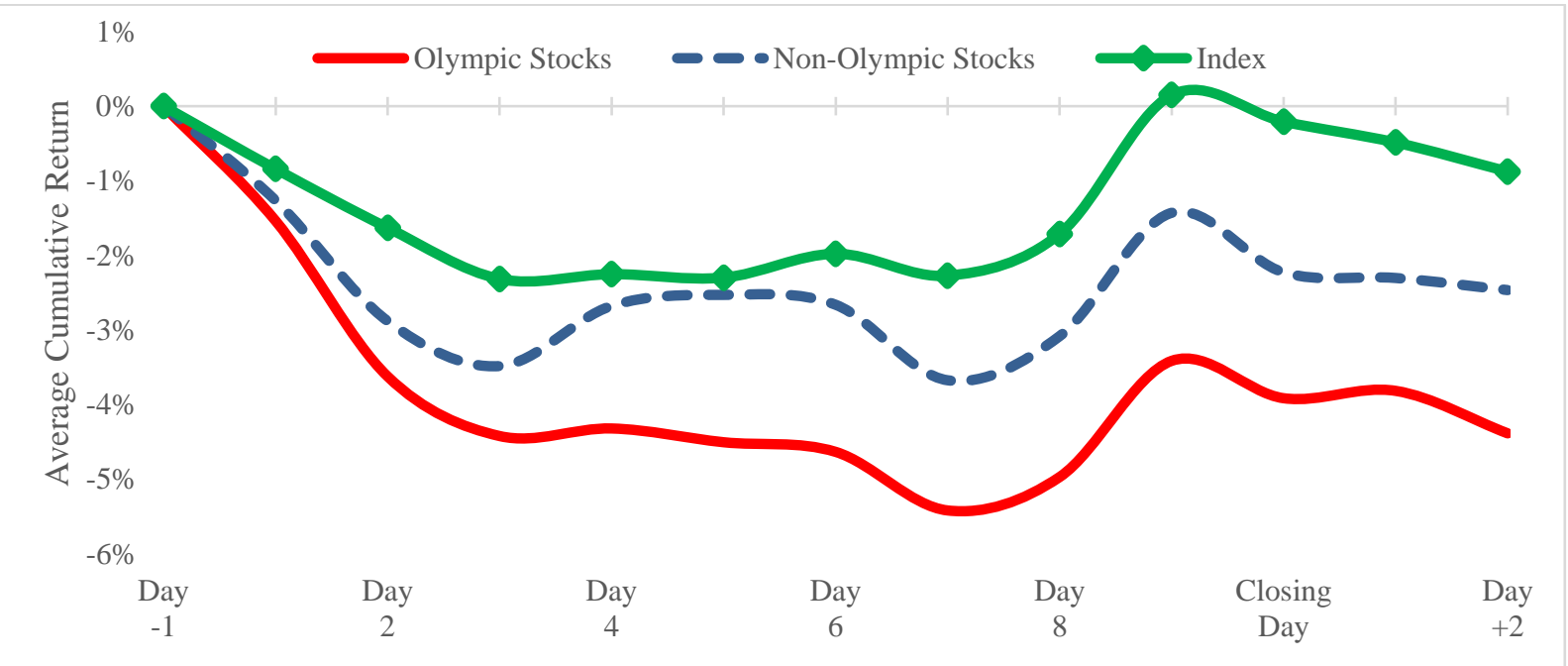

Panel C: Host country stock returns after the Olympic games.

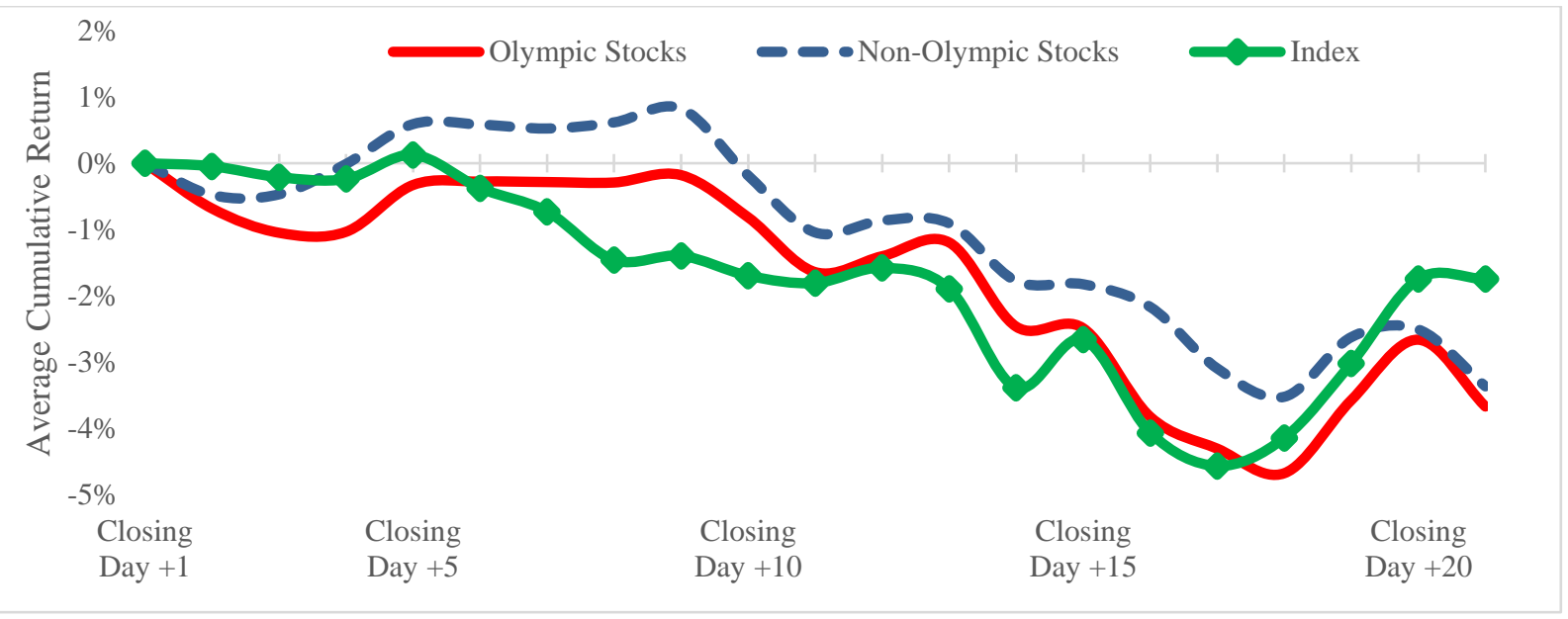


Figure 2 presents the cumulative average return for Olympic stocks, propensity-scored matched non-Olympic stocks, and market index for the five host countries included in our main Olympic sample during the three key Olympic event windows: i) following the winning bid announcement (Panel A); ii) during the Olympic games (Panel B); and iii) following the Olympic games (Panel C). We calculate the cumulative stock or index return for each event day for each host country and then report the average cumulative return across the host countries. The following five host-countries (summer Olympics) included in the figure are: Australia (Sydney, 2000), Greece (Athens, 2004), China (Beijing, 2008), United Kingdom (London, 2012), and Brazil (Rio de Janeiro, 2016). The market indices for each Olympics are the ASX All Ordinaries (Sydney 2000), ATHEX Composite (Athens 2004), Shanghai A Share (Beijing 2008), FTSE 100 (London 2012), and BOVESPA (Rio 2016). Details of the on the propensity-score matching are provided in Table 1. See Appendix B for detailed variable definitions. 
FIGURE 3

Differences in Cumulative Returns between Olympic and Non-Olympic Stocks

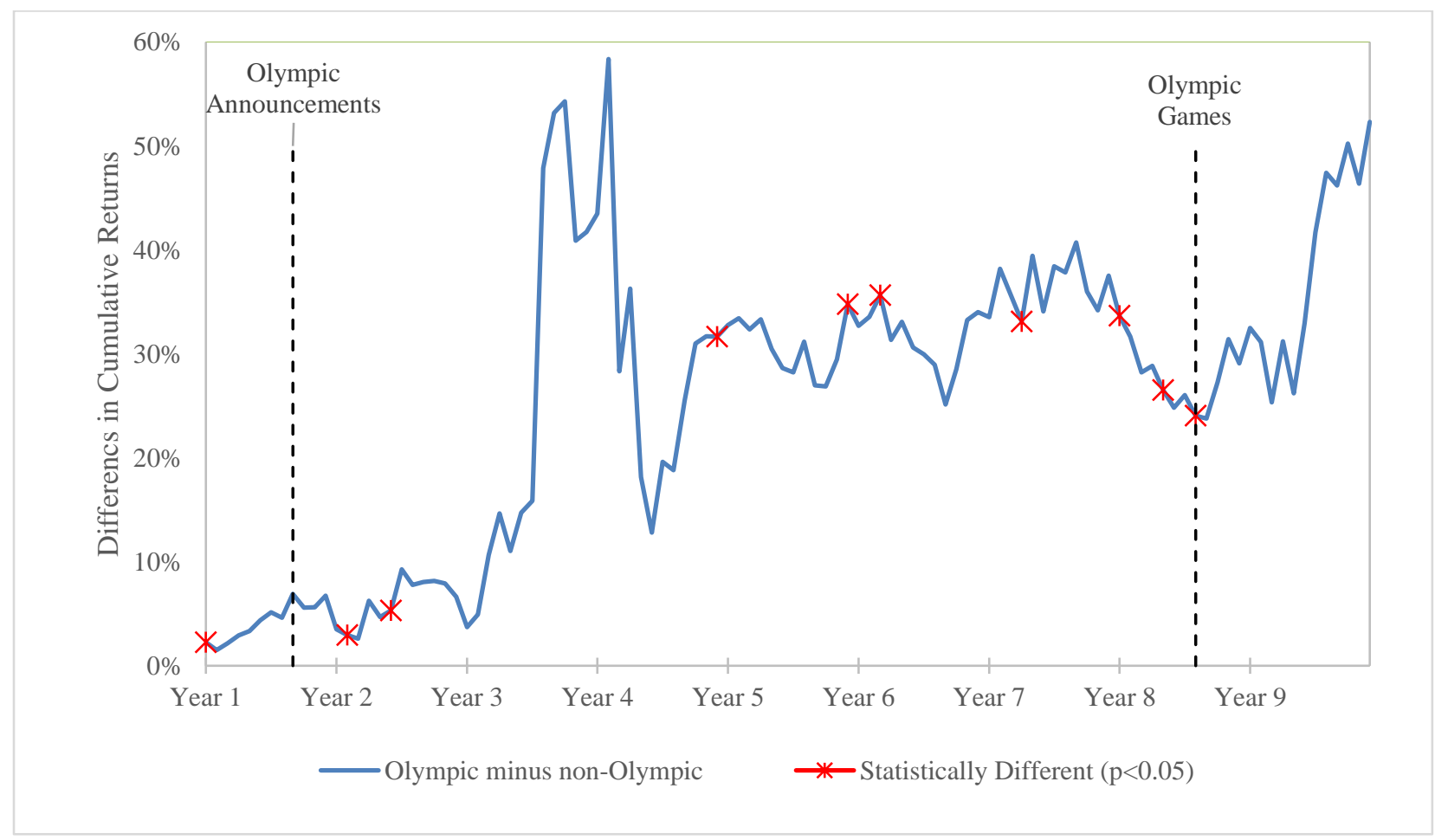

This figure presents the difference in cumulative returns between all Olympic and non-Olympic propensity-score matched stocks. Cumulative returns are computed as the monthly compounded returns, starting in January of the year of the Olympic announcements (year 1) and ending one year after the Olympic Games (year 9). The vertical line "Olympic Announcements" indicates the average month for the announcement of the Olympics (month $8^{\text {th }}$ of year 1) and the vertical line "Olympic Games" shows the average month of the end of the Olympic games (month $8^{\text {th }}$ of year 8 ). The combined sample consists of 213 Olympic stocks and 213 non-Olympic stocks that were publicly traded during the Olympic winning bid announcement. Red stars on the differences in cumulative abnormal return line reflect statistical differences $(\mathrm{p}<0.05)$ between Olympic and non-Olympic stocks using a two-tailed test on the means. Details of the on the propensity-score matching are provided in Table 1. See Appendix B for detailed variable definitions. 


\section{FIGURE 4}

Rolling Monthly Comovements of Olympic Stocks with the Olympic Stock Index and Rolling Monthly Synchronicity

$50 \%$

$60 \%$

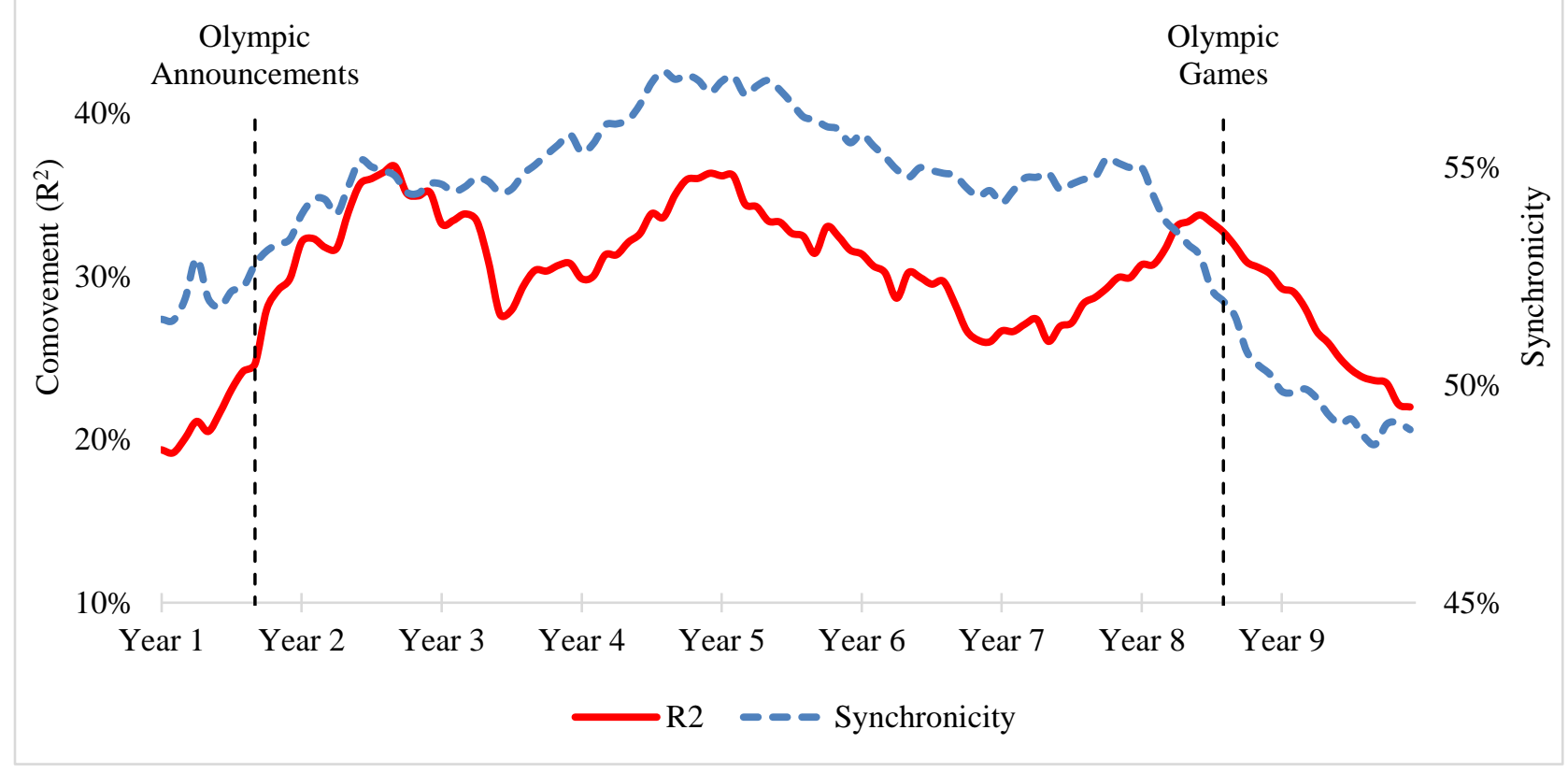

The figure presents monthly rolling comovement (measured as adjusted $\mathrm{R}^{2}$ ) and synchronicity of Olympic stocks from the bid winning announcement to a year after the Olympic Games. Panel A present results for all five Olympics: Australia (Sydney, 2000), Greece (Athens, 2004), China (Beijing, 2008), United Kingdom (London, 2012), and Brazil (Rio de Janeiro, 2016). At the end of each month, we calculate the average adjusted $\mathrm{R}^{2}$ of Olympic firm-specific regressions of daily returns on an Olympic index: Model 1a: Olympic Stock Return $n_{i, t k}=\alpha_{0}+\beta i$ Olympic Index $t_{t, k}+\varepsilon_{i, t, k}$, using daily returns over the preceding year. The daily Olympic stock index returns are the average of the daily returns of all Olympic firms excluding firm $i$. Each day we calculate the percentage of Olympic stocks with returns that are: positive; negative; or zero and we determine the maximum percentage for the day. Synchronicity is calculated as the average maximum percentage over the month. The graph reports the one-year monthly moving average of Synchronicity. Year 1 is the year of the winning bid announcement and year 8 is the year of the Olympic games. The vertical line "Olympic Announcements" indicates the average month for the announcement of the Olympics (month $8^{\text {th }}$ of year 1) and the vertical line "Olympic Games" shows the average month of the end of the Olympic games (month $8^{\text {th }}$ of year 8 ). The combined sample consists of 213 Olympic stocks and 213 non-Olympic stocks that were publicly traded during the Olympic winning bid announcement. 


\section{FIGURE 5}

Number of Mentions of "Olympic" or "Olympics" in the Local Media

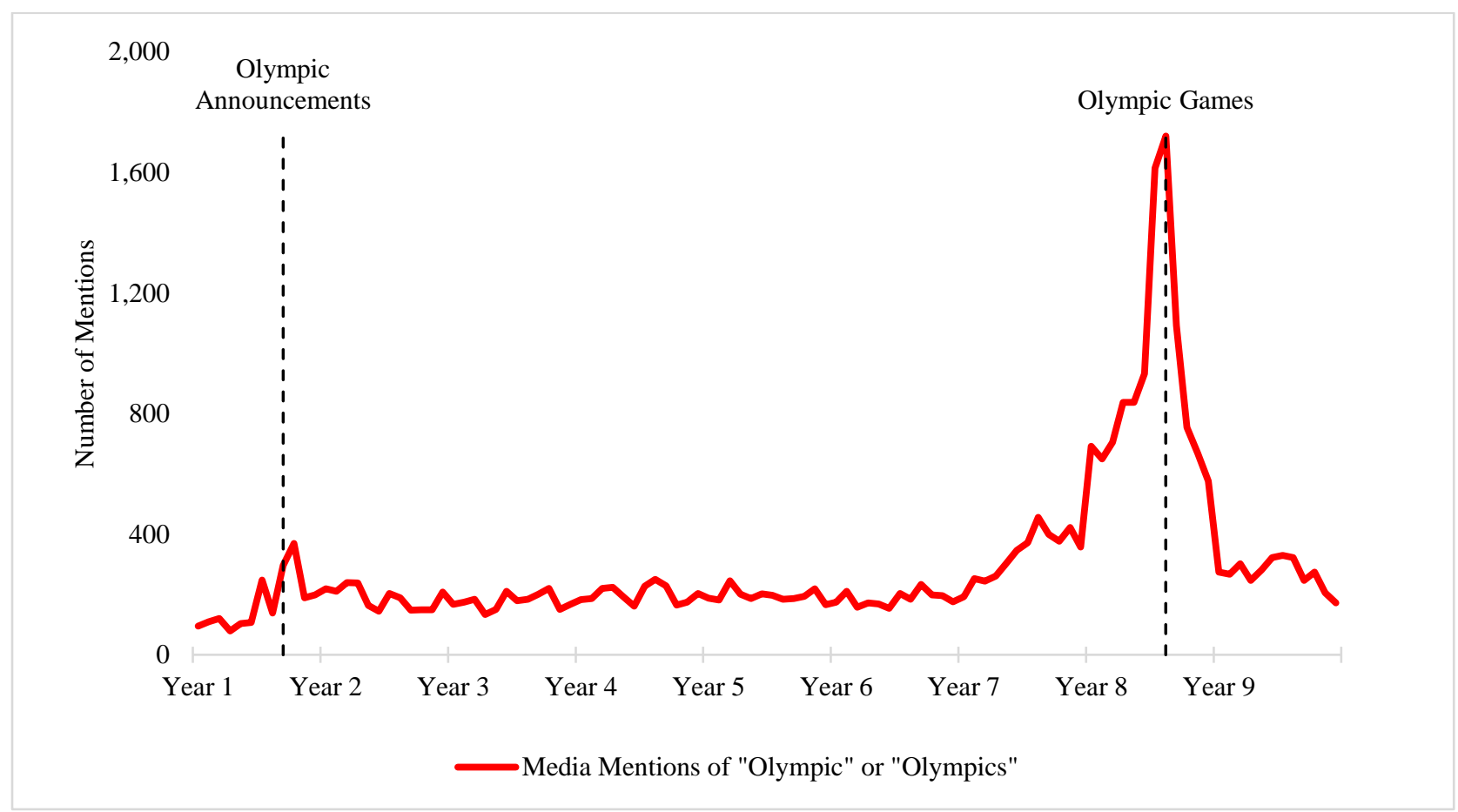

This figure presents monthly results for the number of media mentions for the word Olympic or Olympics in the main media source for each country from the year of the Olympics announcement to the year of the Olympics (see Table 1, Panel A for the Olympics start and end dates). We select the most popular Factiva source for each country: The Australian in English for the Sydney 2000 Olympics, Athens News Agency in English for the Athens 2004 Olympics, China News Service in Chinese for the Beijing 2008 Olympics, The Times in English for the London 2012 Olympics, and O Globo in Portuguese for the Rio 2016 Olympics. Year 1 is the year of the announcement and year $9^{\text {th }}$ is one year after the Olympic games. The vertical line "Olympic Announcements" indicates the average month for the announcement of the Olympics (month $8^{\text {th }}$ of year 1) and the vertical line "Olympic Games" shows the average month of the end of the Olympic games (month $8^{\text {th }}$ of year 8 ). 


\section{FIGURE 6}

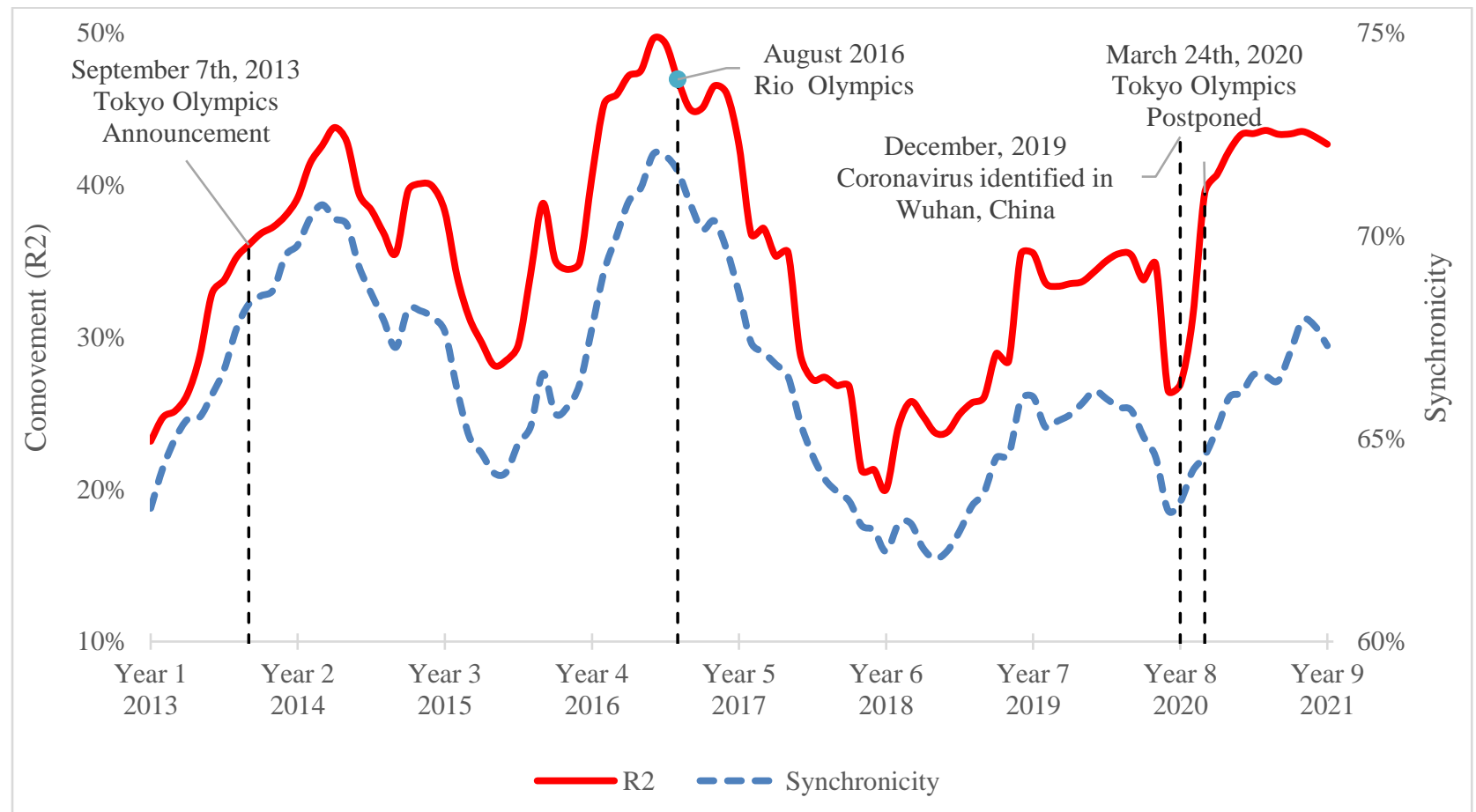

The figure presents monthly rolling comovement (measured as adjusted $\mathrm{R}^{2}$ ) and synchronicity of Olympic stocks for the 2020 Tokyo Olympics from the announcement of the winning bid in 2013 (Year 1) to April 30 ${ }^{\text {th }}, 2021$ as on March 24 ${ }^{\text {th }}, 2020$, the Olympics were delayed from the summer of 2020 to summer 2021 due to the Covid epidemic. At the end of each month, we calculate the average adjusted $\mathrm{R}^{2}$ of Olympic firm-specific regressions of daily returns on an Olympic index: Model 1a: Olympic Stock Return $n_{i, t, k}=\alpha_{0}$ $+\beta_{i}$ Olympic Index $x_{t, k}+\varepsilon_{i, t, k}$, using daily returns over the preceding year. The daily Olympic stock index returns are the average of the daily returns of all Olympic firms excluding firm $i$. Each day we calculate the percentage of Olympic stocks with returns that are: positive; negative; or zero and we determine the maximum percentage for the day. Synchronicity is calculated as the average maximum percentage over the month. The graph reports the one-year monthly moving average of Synchronicity. Year 1 is the year of the winning bid announcement and year 8 is the announcement of the delay of the Olympics until summer 2021. The vertical line "Tokyo Olympics Announcement" indicates the date for the announcement of the Tokyo Olympics (September $\left.7^{\text {th }}, 2013\right)$ and the vertical line "Tokyo Olympics Postponed" shows the date of the Olympic games postponement (March 24 $\left.4^{\text {th }}, 2020\right)$. The Tokyo sample consists of 111 Olympic stocks and 111 non-Olympic stocks that were publicly traded during the Tokyo Olympic winning bid announcement. See Appendix B for details on variable definitions. 
FIGURE 7

2020 Stay-At-Home Comovement, Media Mentions, and Cumulative Returns
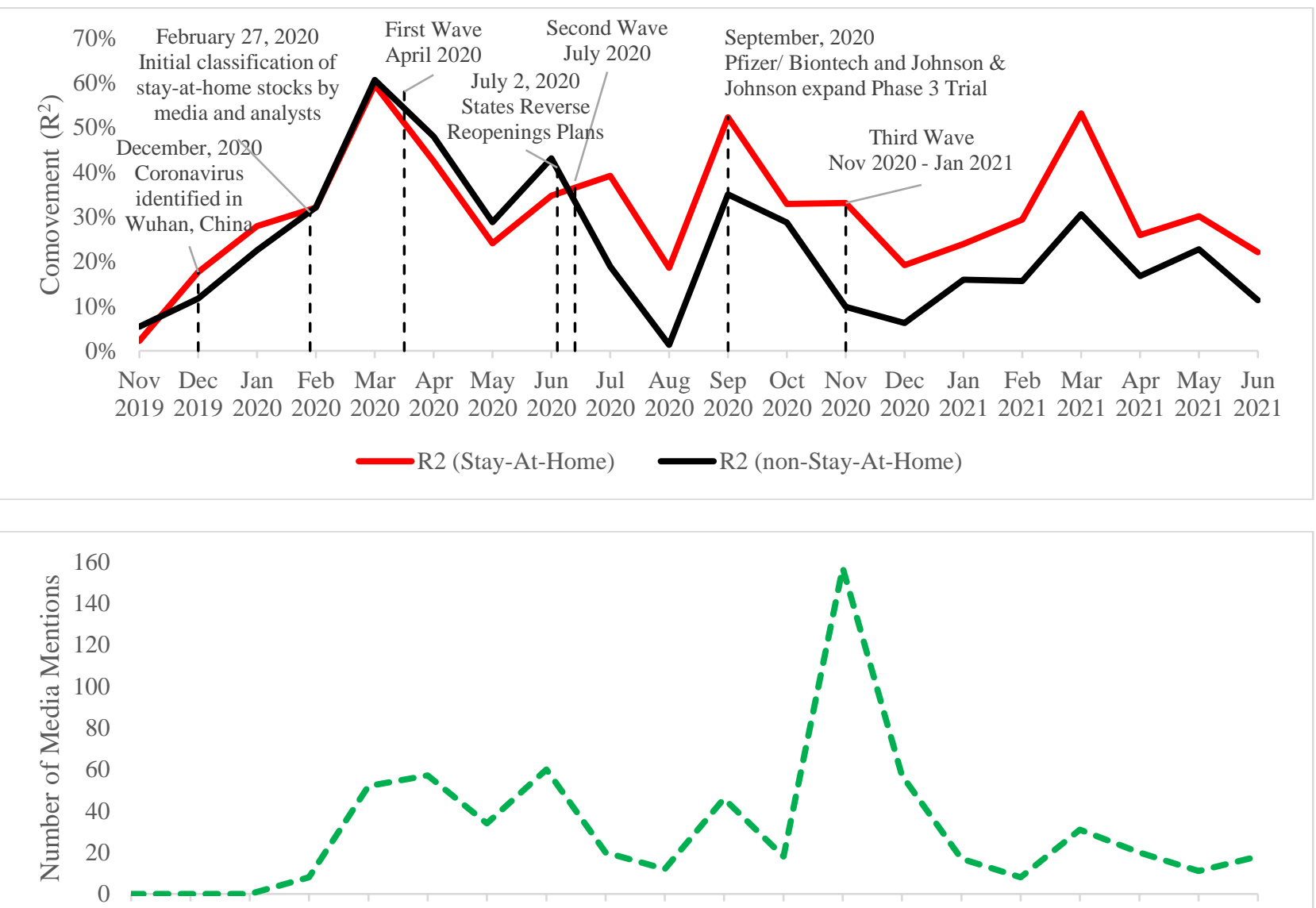

Nov Dec Jan Feb Mar Apr May Jun Jul Aug Sep Oct Nov Dec Jan Feb Mar Apr May Jun 20192019202020202020202020202020202020202020202020202020202120212021202120212021

- Media Mentions for "Stay-at-Home Stock"

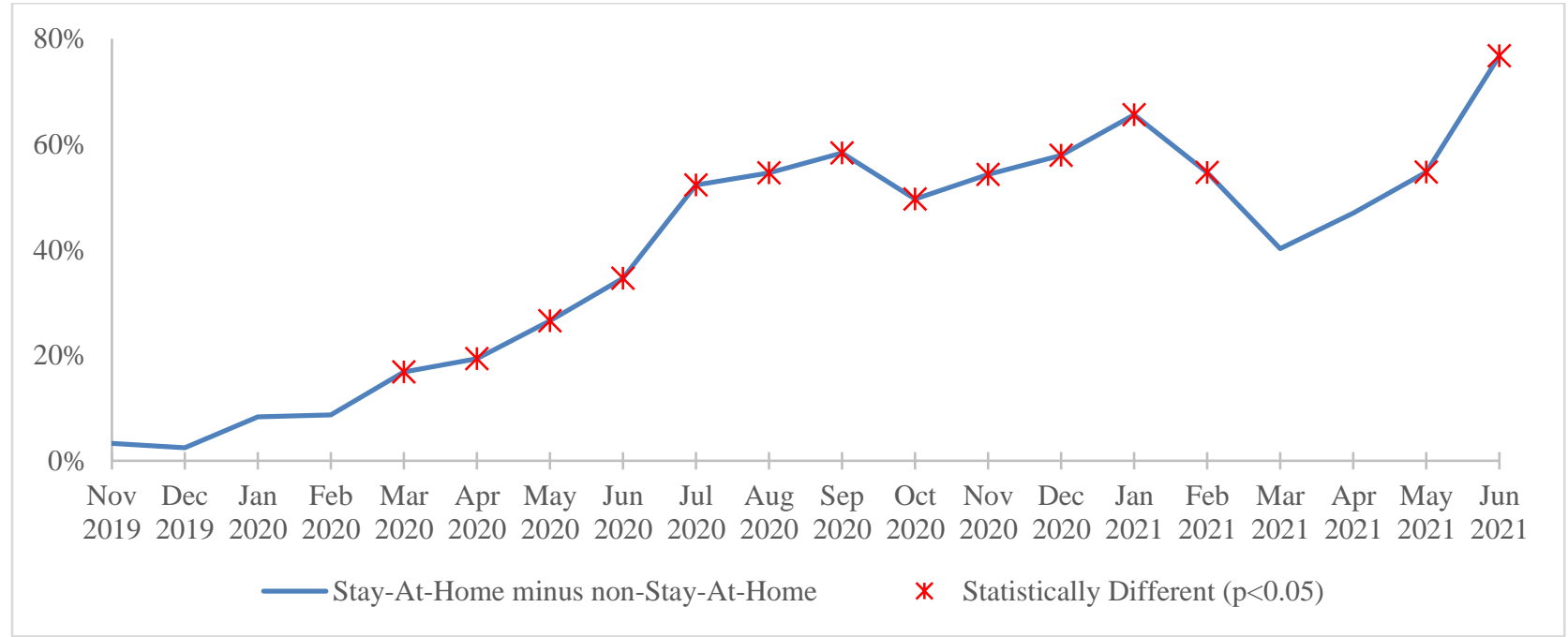


The Stay-at-Home (SAH) sample consists of 46 SAH and 46 non-SAH stocks that were publicly traded during November $1^{\text {st }}, 2019$. We identify the SAH stocks from media mentions in https://realmoney.thestreet.com/jim-cramer, https://www.kiplinger.com/, and https://www.cnbc.com. The figure presents monthly rolling comovement (measured as adjusted $\mathrm{R}^{2}$ ) of stay-at-home (SAH) and propensity-score matched non-stay-at-home stocks (non-SAH), media mentions of the term "Stay-at-Home" and differences in cumulative returns between SAH and non-SAH stocks of from November $1^{\text {st }}, 2019$ to June $30^{\text {th }}, 2021$. The first figure presents results for the comovement. At the end of each calendar month, we calculate the average adjusted $\mathrm{R}^{2}$ of SAH firm-specific regressions of daily returns on a SAH index using Model 1a: SAH Stock $\operatorname{Return}_{i, t k}=\alpha_{0}+\beta_{i} S A H$ Index $_{t, k}+\varepsilon_{i, t, k}$, using daily returns over the preceding month. The daily SAH stock index returns are the average of the daily returns of all SAH firms excluding firm $i$. Similarly, at the end of each month, we calculate the average adjusted $\mathrm{R}^{2}$ of non-SAH firm-specific regressions of daily returns on a non-SAH index using Model 1b: Non-SAH Stock Return ${ }_{i, t}=\alpha_{0}+\beta i N o n-S A H$ Index $_{t, k}+\varepsilon_{i, t, k}$, using daily returns over the preceding month. The daily non-SAH stock index returns are the average of the daily returns of all propensity-score matched non-SAH firms excluding firm $i$. We match SAH stocks to their comparable non-SAH stocks using 1:1 propensity-score matching and industry fixed effects. We match on firm characteristics one year before the 2020 SAH stock movement: total assets, market capitalization, book-to-market, earnings-to-price, ROA and CFO. The second figure presents results for the Number of Media Mentions is the number of Factiva mentions in the United States for the word combinations "stay-at-home stock", "stay-at-home stocks", "work-from-home stock", and "work-from-home stocks". The third figure presents results for the differences in cumulative returns between SAH and non-SAH stocks. See Appendix B for details on variable definitions and https://www.aarp.org/health/conditions-treatments/info-2021/covid-4th-wave.html for the source used for identifying the COVID-19 waves. 


\section{FIGURE 8}

2021 Meme Stock Comovement, Google Trends, and Cumulative Returns
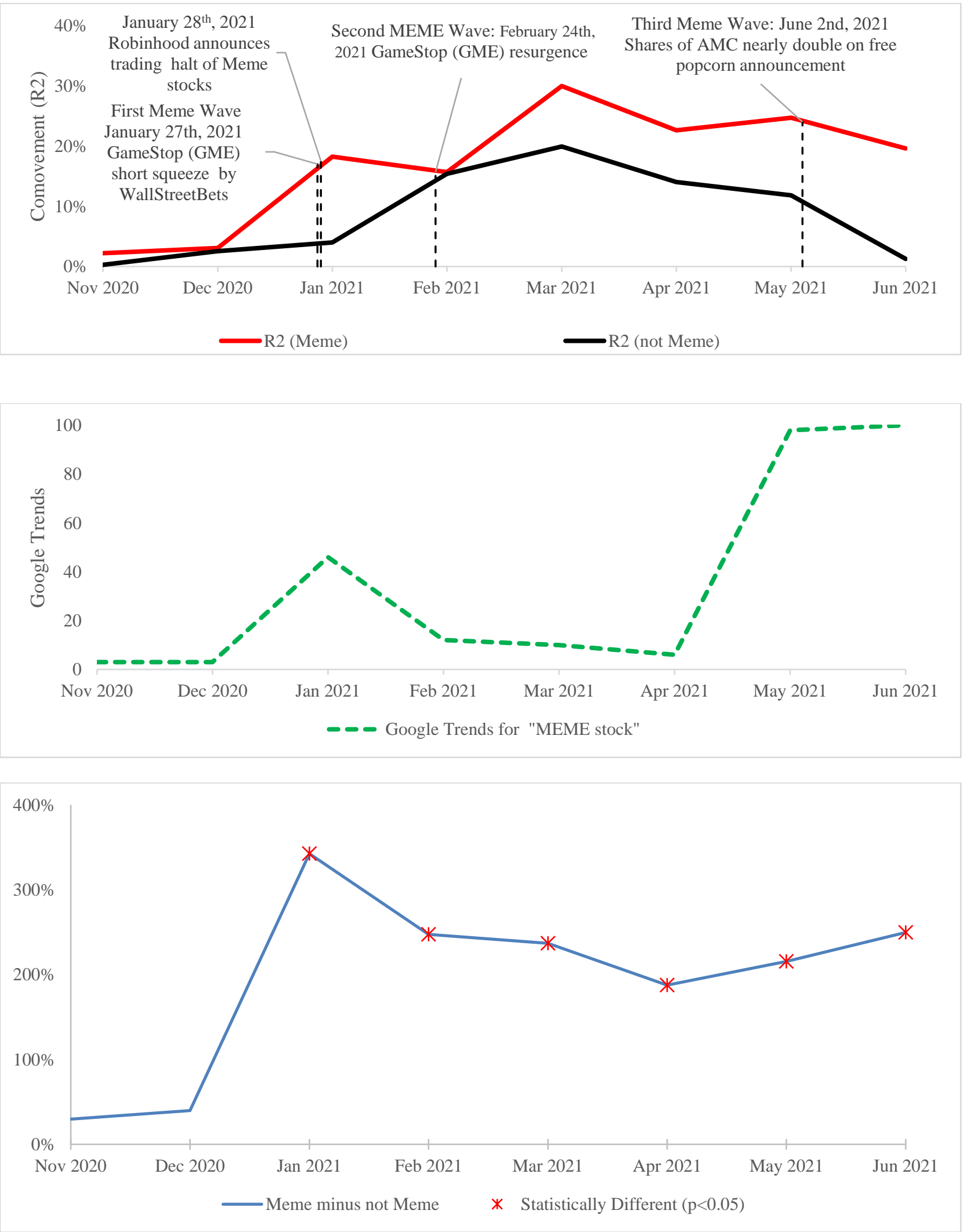
The Meme sample consists of 44 Meme and 44 not Meme stocks that were publicly traded during November $1^{\text {st }}, 2020$. We identify Meme stocks from the list of 50 stocks where Robinhood restricted trading in January 2021 (see https://finance.yahoo.com/news/robinhood-expands-trading-restrictions-50-225241993.html ). The figure presents monthly rolling comovement (measured as adjusted $\mathrm{R}^{2}$ ) of Meme, propensity-score matched not Meme stocks, Google Trends for the term "Meme stock", and difference in cumulative returns between Meme and not Meme stocks from November $1^{\text {st }}, 2020$ to June $30^{\text {th }}, 2021$. The first figure presents results for the comovement. At the end of each month, we calculate the average adjusted $\mathrm{R}^{2}$ of Meme firm-specific regressions of daily returns on a Meme index using Model 1a: Meme Stock Return ${ }_{i, t k}=\alpha_{0}+\beta_{i}$ Meme Index $_{t, k}+\varepsilon_{i, t, k}$, using daily returns over the preceding month. The daily Meme stock index returns are the average of the daily returns of all Meme firms excluding firm $i$. Similarly, at the end of each month, we calculate the average adjusted $\mathrm{R}^{2}$ of not MEME firm-specific regressions of daily returns on a not Meme index using Model 1b: Not Meme Stock Return $i_{i, t}=\alpha_{0}+\beta_{i}$ Not Meme Index $t_{t, k}+\varepsilon_{i, t, k}$, using daily returns over the preceding month. The daily not Meme stock index returns are the average of the daily returns of all propensity-score matched not Meme firms excluding firm $i$. We match Meme stocks to their comparable not MEME stocks using 1:1 propensity-score matching and industry fixed effects. We match on firm characteristics one year before the 2021 Meme stock movement: total assets, market capitalization, book-to-market, earnings-to-price, ROA, CFO, and short interest as a percentage of shares outstanding. The two leading Meme stocks, GameStop and AMC, were used to identify the three Meme waves in the first half of 2021. The second figure presents results for the Google Trends for the term "Meme stock" which represents the maximum search interest for each month relative to the highest point on the chart for United States for the period November $1^{\text {st }}, 2020$ to June $30^{\text {th }}, 2021$. A value of 100 is the peak popularity for the term. A value of 50 means that the term is half as popular as the peak. A value of 0 means there was not enough data for this term. The third figure presents results for the differences in cumulative returns between Meme and not Meme stocks, all differences are significant at conventional levels starting in January, 2021. See Appendix B for details on variable definitions. 
TABLE 1

Olympics Covered, Industry Classifications, and Descriptive Statistics

Panel A: Summer Olympics between 2000 to 2016 used to identify Olympic stocks

\begin{tabular}{|c|c|c|c|c|c|}
\hline $\begin{array}{l}\text { Winning bid } \\
\text { Announced }\end{array}$ & $\begin{array}{l}\text { Olympics } \\
\text { Start }\end{array}$ & $\begin{array}{l}\text { Olympics } \\
\text { End }\end{array}$ & $\begin{array}{l}\text { Hosting } \\
\text { City }\end{array}$ & $\begin{array}{l}\text { Hosting } \\
\text { Country }\end{array}$ & Market Indices \\
\hline $09 / 24 / 1993$ & $09 / 15 / 2000$ & $10 / 01 / 2000$ & Sydney & Australia & ASX All Ordinaries \\
\hline 09/05/1997 & 08/13/2004 & $08 / 29 / 2004$ & Athens & Greece & ATHEX Composite \\
\hline $07 / 13 / 2001$ & 08/08/2008 & $08 / 24 / 2008$ & Beijing & China & $\begin{array}{l}\text { Shanghai A Share and } \\
\text { Shenzhen Index }\end{array}$ \\
\hline 07/06/2005 & 07/27/2012 & $08 / 12 / 2012$ & London & UK & $\begin{array}{l}\text { FTSE 100, FTSE All } \\
\text { Shares, and AIM index }\end{array}$ \\
\hline $10 / 02 / 2009$ & 08/05/2016 & $08 / 21 / 2016$ & Rio de Janeiro & Brazil & Bovespa \\
\hline
\end{tabular}

Panel B: Industry distribution of Olympic stocks by country

\begin{tabular}{lcccccc}
\hline Industry Name & Australia & Greece & China & UK & Brazil & Total \\
\hline Engineering \& Construction & 1 & 14 & 1 & 10 & 0 & 26 \\
Real Estate Development & 3 & 1 & 13 & 0 & 4 & 21 \\
Hotels/Resorts/Cruise Lines & 3 & 1 & 1 & 1 & 1 & 7 \\
Beverages: Alcoholic & 2 & 0 & 2 & 2 & 0 & 6 \\
Department Stores & 0 & 0 & 4 & 2 & 0 & 6 \\
Homebuilding & 0 & 0 & 0 & 5 & 1 & 6 \\
Broadcasting & 3 & 0 & 1 & 1 & 0 & 5 \\
Construction Materials & 0 & 2 & 2 & 1 & 0 & 5 \\
Major Banks & 2 & 1 & 0 & 1 & 1 & 5 \\
Other Transportation & 1 & 0 & 1 & 2 & 1 & 5 \\
Steel & 0 & 0 & 2 & 1 & 2 & 5 \\
Other & 22 & 22 & 33 & 34 & 5 & 116 \\
\hline Total & 37 & 41 & 60 & 60 & 15 & 213 \\
\hline
\end{tabular}

Panel C: Industry distribution of non-Olympic stocks by country

\begin{tabular}{lcccccc}
\hline Industry & Australia & Greece & China & UK & Brazil & Total \\
\hline Real Estate Development & 0 & 0 & 10 & 1 & 4 & 15 \\
Engineering \& Construction & 0 & 7 & 1 & 3 & 0 & 11 \\
Other Transportation & 0 & 0 & 4 & 3 & 0 & 7 \\
Agricultural Commodities/Milling & 0 & 2 & 3 & 1 & 0 & 6 \\
Building Products & 1 & 2 & 0 & 3 & 0 & 6 \\
Electrical Products & 0 & 1 & 3 & 2 & 0 & 6 \\
Major Banks & 2 & 0 & 0 & 3 & 1 & 6 \\
Beverages: Alcoholic & 2 & 0 & 1 & 2 & 0 & 5 \\
Construction Materials & 1 & 2 & 2 & 0 & 0 & 5 \\
Publishing: Newspapers & 2 & 3 & 0 & 0 & 0 & 5 \\
Regional Banks & 1 & 3 & 0 & 0 & 1 & 5 \\
Other & 28 & 21 & 36 & 42 & 9 & 136 \\
\hline Total & 37 & 41 & 60 & 60 & 15 & 213 \\
\hline
\end{tabular}




\section{TABLE 1 (CONT.)}

\section{Panel D: Characteristics of Olympic and non-Olympic stocks}

\begin{tabular}{lcccc|cccc}
\hline & \multicolumn{3}{c}{ Unique } & Olympic Firms $(\mathrm{n}=213)$ & \multicolumn{4}{c}{ Unique Non-Olympic Firms (n=213) } \\
\cline { 2 - 10 } & Mean & Median & Q1 & Q3 & Mean & Median & Q1 & Q3 \\
\hline Total Assets (Million USD) & 5,295 & 242 & 98 & 814 & 1,665 & 193 & 76 & 621 \\
Market Cap. (Million USD) & 1,553 & 464 & 178 & 1,076 & 765 & 408 & 81 & 815 \\
Book-to-Market & 0.86 & 0.64 & 0.38 & 1.00 & 0.99 & 0.67 & 0.38 & 1.31 \\
Earnings-to-Price & 0.04 & 0.08 & 0.04 & 0.14 & 0.08 & 0.07 & 0.04 & 0.13 \\
Return on Assets (ROA) & 0.79 & 0.06 & 0.03 & 0.10 & 0.51 & 0.05 & 0.03 & 0.09 \\
Cash Flow from Operations (CFO) & 0.06 & 0.07 & 0.02 & 0.11 & 0.07 & 0.07 & 0.01 & 0.12 \\
Cumulative Return & 1.43 & 0.71 & $-0.15^{* *}$ & 1.97 & 1.35 & 0.46 & -0.36 & 2.25 \\
Assets_E & 3.40 & 2.08 & 1.50 & 3.27 & 3.61 & 2.09 & 1.53 & 2.82 \\
Return on Equity (ROE) & 0.12 & 0.11 & 0.06 & 0.20 & 0.14 & 0.11 & 0.05 & 0.18 \\
Revenue_E & 2.77 & 1.52 & 0.70 & 3.08 & 2.68 & 1.52 & 0.63 & 2.91 \\
\hline
\end{tabular}

Table 1 presents information on the five summer Olympics used in our main analyses and descriptive statistics for all Olympic and propensity-score matched non-Olympic stocks as of the Olympic announcement year. The sample consists of 213 Olympic stocks and 213 non-Olympic stocks that were publicly traded during the Olympic winning bid announcement. We match Olympic stocks to their comparable non-Olympic stocks using 1:1 propensity score matching and industry fixed effects. We match on firm characteristics one year before the Olympics announcement: total assets, market capitalization, book-to-market, earnings-to-price, ROA, and CFO. Panel A presents the key dates and respective market indices used for each of the five summer Olympics. Panels B and $\mathrm{C}$ illustrate the distributions of Olympic and non-Olympic stocks, respectively, for each industry and each country. Panel D summarizes the individual characteristics of Olympic and non-Olympic firms one year before the announcement of the Olympics. Total Assets is the total assets in USD reported as of the fiscal year-end. Market Cap is the market capitalization in USD as of the fiscal year-end. Book-to-Market is the book value of equity as of the fiscal year-end scaled by the market value of equity as of the fiscal year-end. Earnings-to-Price is net income as of the fiscal year-end scaled by the market value of equity as of the fiscal yearend. Return on Assets is computed as fiscal year earnings scaled by average assets. Cash Flow from Operations is computed as fiscal year cash flows from operations scaled by average assets. Cumulative Return is the cumulative return from the year of the announcement of the Olympics to the year of the end of the Olympic games. Assets_E is of annual assets divided by average book value of equity. ROE is annual net income divided by average book value of equity. Revenue_E is annual revenues divided by average book value of equity. $* * *, * *$, and $*$ denote statistical significance between Olympic stocks and non-Olympic stocks at the one, five, and ten percent levels, respectively, using two-tailed t-tests on the means and Wilcoxon tests on the medians. 


\section{TABLE 2}

Comovements of Olympic Stocks with the Olympic Stock Index

Olympic Stock Return $n_{i, t, k}=\alpha_{0}+\beta i$ Olympic Index ${ }_{t, k}+\varepsilon_{i, t, k}$

\begin{tabular}{|c|c|c|c|}
\hline Period & \multicolumn{2}{|c|}{ Period Description } & $\mathbf{R}^{2}$ Olympic \\
\hline Pre-Announcement Years & \multicolumn{2}{|c|}{ The 3 years prior to the announcement } & 0.226 \\
\hline Middle Years & \multicolumn{2}{|c|}{ The 7 years after announcement } & 0.264 \\
\hline Olympic Years & \multicolumn{2}{|c|}{ The year of the Olympic games } & 0.283 \\
\hline Post-Game Years & \multicolumn{2}{|c|}{ The 3 years after the Olympic games } & 0.204 \\
\hline \multirow{7}{*}{ Predicted Sign } & \multirow{2}{*}{$\mathrm{R}^{2}$ Olympic +} & Pre-Announcement Years & $\mathbf{0 . 0 3 9} * * *$ \\
\hline & & v.s. Middle Years & $(\mathbf{0 . 0 1})$ \\
\hline & \multirow{2}{*}{$\mathrm{R}^{2}$ Olympic +} & Middle Years & $0.018 * *$ \\
\hline & & v.s. Olympic Years & $(0.05)$ \\
\hline & \multirow{2}{*}{$\mathrm{R}^{2}$ Olympic - } & Olympic Years & $-0.078 * * *$ \\
\hline & & v.s. Post-Game Years & $(\mathbf{0 . 0 0})$ \\
\hline & & & $\mathrm{N}=213$ \\
\hline
\end{tabular}

This table presents descriptive results and test statistics of comovements for Olympic stocks over three years prior to the Olympic winning bid announcement year, seven years prior to the Olympic Games, the year of the Olympic games, and three years after the Olympic games, separately. The top four rows present the average adjusted $\mathrm{R}^{2}$ of Olympic firm-specific regressions of daily returns on an Olympic index (Model 1) during the four foregoing game periods. Olympic Stock Return $i, t, k$ is the daily return for each Olympic stock in country k. Olympic Index $x_{t, k}$ is the average of the daily returns of all Olympic firms in each country $k$ excluding firm $i$. The bottom rows present changes in adjusted $\mathrm{R}^{2}$ over the respective periods. P-values in parenthesis denote statistical significance from one-sided t-tests of changes in $\mathrm{R}^{2}$ for directional predictions. $* * * * *$, and $*$ denote statistical significance at the one, five, and ten percent levels, respectively, using one-tailed test. The Olympic sample consists of 213 Olympic stocks that were publicly traded during the Olympic winning bid announcement. See Appendix B for detailed variable definitions. 
TABLE 3

Comovements of Olympic and non-Olympic Stocks with the Market Index

Olympic Stock Return $n_{i, t, k}=\alpha_{0}+\beta_{i}$ Market Index ${ }_{t, k}+\varepsilon_{i, t, k}$

Non-Olympic Stock Return ${ }_{i, t, k}=\alpha_{0}+\beta_{i}$ Market Index $_{t, k}+\varepsilon_{i, t, k}$

\begin{tabular}{|c|c|c|c|c|c|}
\hline Period & \multicolumn{2}{|c|}{ Period Description } & $\mathrm{R}^{2}$ Olympic & $\mathrm{R}_{\text {non-Olympic }}^{2}$ & Difference \\
\hline Pre-Announcement Years & \multicolumn{2}{|c|}{ The 3 years prior to the announcement } & 0.205 & 0.172 & $\begin{array}{l}\mathbf{0 . 0 3 3}^{* *} \\
(\mathbf{0 . 0 3})\end{array}$ \\
\hline Middle Years & \multicolumn{2}{|c|}{ The 7 after the announcement } & 0.232 & 0.182 & $\begin{array}{l}\mathbf{0 . 0 5 0} * * * \\
(\mathbf{0 . 0 0 )}\end{array}$ \\
\hline Olympic Years & \multicolumn{2}{|c|}{ The year of the Olympic games } & 0.260 & 0.204 & $\begin{array}{l}0.056 * * * \\
(0.01)\end{array}$ \\
\hline Post-Game years & \multicolumn{2}{|c|}{ The 3 years after the Olympic games } & 0.178 & 0.150 & $\begin{array}{l}0.028 * * \\
(0.02)\end{array}$ \\
\hline \multirow{4}{*}{ Predicted Sign } & $\mathrm{R}^{2}$ Olympic + & $\begin{array}{l}\text { Pre-Announcement Years } \\
\text { v.s. Middle Years }\end{array}$ & $\begin{array}{l}\mathbf{0 . 0 2 7} \\
(0.04)\end{array}$ & $\begin{array}{l}0.010 \\
(0.25)\end{array}$ & $\begin{array}{l}0.016 * * \\
(0.03)\end{array}$ \\
\hline & $\mathrm{R}^{2}$ Olympic + & $\begin{array}{l}\text { Middle Years } \\
\text { v.s. Olympic Years }\end{array}$ & $\begin{array}{l}0.028 \\
(0.05)\end{array}$ & $\begin{array}{l}0.022 \\
(0.11)\end{array}$ & $\begin{array}{l}\text { 0.006* } \\
(0.10)\end{array}$ \\
\hline & \multirow[t]{2}{*}{$\mathrm{R}^{2}$ Olympic - } & $\begin{array}{l}\text { Olympic Years } \\
\text { v.s. Post-Game Years }\end{array}$ & $\begin{array}{r}-0.082 \\
(0.00)\end{array}$ & $\begin{array}{l}-0.054 \\
(\mathbf{0 . 0 0 )}\end{array}$ & $\begin{array}{l}-0.027 * * \\
(0.05)\end{array}$ \\
\hline & & & $\mathrm{N}=213$ & $\mathrm{~N}=213$ & \\
\hline
\end{tabular}

This table presents descriptive results and test statistics of comovements for Olympic and their propensity-score matched non-Olympic stocks over three years prior to the Olympics winning bid announcement year, seven years prior to the Olympic Games, the year of the Olympic games, and three years after the games, separately. The table presents average adjusted $\mathrm{R}^{2}$ from Olympic firm-specific regressions of daily returns on daily market index returns (Model 2a), and non-Olympic firm-specific regressions of daily returns on the market index returns (Model 2b) using all Olympic and non-Olympic stocks for the foregoing periods. Olympic Stock Return $n_{i, t, k}$ is the daily return for each Olympic stock in country $k$. Non-Olympic Stock Return ${ }_{i, t, k}$ is the daily return for each stock matched nonOlympic stock in country $k$. Market Index $t_{t, k}$, is the daily market index returns for each country $k$ : ASX All for Sydney (2000); ATHEX Composite for Athens (2004); Shanghai A Share or Shenzhen Index for Beijing (2008); FTSE All Shares or AIM index for London (2012); and BOVESPA Index for Rio (2016). P-values in parenthesis denote statistical significance from one-sided t-tests of changes in adjusted $\mathrm{R}^{2}$ for directional predictions over the respective periods, and also the difference in those changes between Olympic and non-Olympic stocks. $* * *, * *$, and * denote statistical significance at the one, five, and ten percent levels, respectively, using onetailed test. The sample consists of 213 Olympic stocks and 213 non-Olympic stocks that were publicly traded during the Olympic winning bid announcement. Details of the on the propensity-score matching and the respective indices used for each country are provided in Table 1. See Appendix B for detailed variable definitions 
TABLE 4

Comovements of Olympic Stocks with the Olympic and Non-Olympic Stock Indices

Olympic Stock Return ${ }_{i, t, k}=\alpha_{0}+\beta_{l i}$ Olympic Index ${ }_{t, k}+\beta_{2 i}$ Non-Olympic Index $x_{t, k}+\varepsilon_{i, t, k}$

(3)

\begin{tabular}{|c|c|c|c|c|c|c|}
\hline Period & \multicolumn{3}{|c|}{ Period Description } & $\beta_{\text {Olympic }}$ & $\beta_{\text {non-Olympic }}$ & Difference \\
\hline $\begin{array}{l}\text { Pre-Announcement } \\
\text { Years }\end{array}$ & \multicolumn{3}{|c|}{ The 3 years prior to the announcement } & 0.561 & 0.374 & $\begin{array}{l}0.187 * * * \\
(0.00)\end{array}$ \\
\hline Middle Years & \multicolumn{3}{|c|}{ The 7 years after the announcement } & 0.613 & 0.361 & $\begin{array}{l}0.252 * * * \\
(0.00)\end{array}$ \\
\hline Olympic Years & \multicolumn{3}{|c|}{ The year of the Olympic Games } & 0.712 & 0.240 & $\begin{array}{l}0.472 * * * \\
(0.00)\end{array}$ \\
\hline \multirow[t]{2}{*}{ Post-Game Years } & \multicolumn{3}{|c|}{ The 3 years after the Olympic Games } & 0.671 & 0.228 & $\begin{array}{l}0.443 * * * \\
(0.00)\end{array}$ \\
\hline & $\beta_{\text {Olympic }}+$ & $\beta_{\text {non-Olympic - }}$ & $\begin{array}{l}\text { Pre-Announcement Years } \\
\text { v.s. Middle Years }\end{array}$ & $\begin{array}{l}0.052 \\
(0.05)\end{array}$ & $\begin{array}{l}-0.013 \\
(0.35)\end{array}$ & $\begin{array}{l}0.065 * * \\
(0.04)\end{array}$ \\
\hline \multirow[t]{3}{*}{ Predicted Sign } & $\beta_{\text {Olympic }}+$ & $\beta_{\text {non-Olympic - }}$ & $\begin{array}{l}\text { Middle Years } \\
\text { v.s. Olympic Years }\end{array}$ & $\begin{array}{l}0.099 \\
(0.01)\end{array}$ & $\begin{array}{l}-0.121 \\
(0.00)\end{array}$ & $\begin{array}{l}0.220 * * * \\
(0.00)\end{array}$ \\
\hline & \multirow[t]{2}{*}{$\beta_{\text {Olympic - }}$} & \multirow[t]{2}{*}{$\beta_{\text {non-Olympic }}+$} & $\begin{array}{l}\text { Olympic Years } \\
\text { v.s. Post-Game Years }\end{array}$ & $\begin{array}{l}-0.042 \\
(0.05)\end{array}$ & $\begin{array}{l}-0.012 \\
(0.37)\end{array}$ & $\begin{array}{l}-0.030 * * \\
(0.03)\end{array}$ \\
\hline & & & & $\mathrm{N}=213$ & $\mathrm{~N}=213$ & \\
\hline
\end{tabular}

This table presents descriptive results and test statistics of the comovements for Olympic stocks over three years prior to the Olympics winning bid announcement year, seven years prior to the Olympic Games, the year of the Olympic Games, and three years after the Games, separately. The table presents average beta coefficients from estimating Model 3 using all Olympic stocks. The top four rows present the average coefficients of Olympic firm-specific regressions of daily returns on an Olympic index and an non-Olympic index (Model 3) during the foregoing periods. Olympic Index $t_{t, k}$ is the average of the daily returns of all Olympic firms in each country $k$ excluding firm $i$. Non-Olympic Index $x_{t, k}$ is the average of the daily returns of all propensity score matched non-Olympic firms in each country $k$. The bottom rows present changes in beta coefficients over the respective periods. P-values in parenthesis denote statistical significance from one-sided t-tests of changes in beta coefficients for directional predictions. ***, **, and * denote statistical significance at the one, five, and ten percent levels, respectively, using one-tailed test. The sample consists of 213 Olympic stocks and 213 non-Olympic stocks that were publicly traded during the Olympic winning bid announcement. See Appendix B for detailed variable definitions. 
TABLE 5

Multivariate Analysis of Comovement During Olympic Periods

\begin{tabular}{|c|c|c|c|}
\hline \multirow[t]{2}{*}{ Dependent Variable: } & \multirow{2}{*}{$\begin{array}{l}\text { Predicted } \\
\text { Sign }\end{array}$} & \multicolumn{2}{|c|}{ Comovement } \\
\hline & & $\begin{array}{l}\mathbf{R}^{2} \text { Model1 } \\
\text { (1) }\end{array}$ & $\begin{array}{c}\mathbf{R}^{2} \text { Model1 } \\
\text { (2) }\end{array}$ \\
\hline Olympic & & $\begin{array}{l}0.041 * * * \\
(5.73)\end{array}$ & $\begin{array}{l}0.042 \text { *** } \\
(4.26)\end{array}$ \\
\hline Middle and Olympic Years & & $\begin{array}{l}0.064 * * * \\
(8.20)\end{array}$ & \\
\hline Olympic * Middle and Olympic Years & $(+)$ & $\begin{array}{l}0.012 * * \\
(1.84)\end{array}$ & \\
\hline Middle Years & & & $\begin{array}{l}0.060 \text { *** } \\
(6.87)\end{array}$ \\
\hline Olympic Years & & & $\begin{array}{l}0.056^{* * * *} \\
(4.65)\end{array}$ \\
\hline Post-Game Years & & & $\begin{array}{l}-0.007 \\
(-0.90)\end{array}$ \\
\hline Olympic * Middle Years & $(+)$ & & $\begin{array}{l}0.021 * * \\
(1.80)\end{array}$ \\
\hline Olympic * Olympic Years & $(+)$ & & $\begin{array}{l}0.014 * * \\
(1.75)\end{array}$ \\
\hline Olympic * Post-Game Years & (n.a.) & & $\begin{array}{l}0.001 \\
(0.36)\end{array}$ \\
\hline Log of Total Assets & & $\begin{array}{l}0.033 * * * \\
(12.48)\end{array}$ & $\begin{array}{l}0.033 * * * \\
(12.37)\end{array}$ \\
\hline ROA & & $\begin{array}{l}-0.002 \\
(-1.12)\end{array}$ & $\begin{array}{l}-0.003 \\
(-1.13)\end{array}$ \\
\hline $\mathrm{CFO}$ & & $\begin{array}{l}-0.041 \\
(-1.59)\end{array}$ & $\begin{array}{l}-0.042 \\
(-1.50)\end{array}$ \\
\hline Observations & & 4,222 & 4,222 \\
\hline Unique Firms & & 422 & 422 \\
\hline R-squared & & 0.643 & 0.643 \\
\hline Country FEs & & Yes & Yes \\
\hline Year FEs & & Yes & Yes \\
\hline Industry FEs & & Yes & Yes \\
\hline
\end{tabular}

This table reports the results of regression of the adjusted $\mathrm{R}^{2}$ from Models (1a and 1b) on an indicator for Olympic or non-Olympic stocks (Olympic) and indicators for the different Olympic periods: middle years (Middle Years), Olympic years (Olympic Years), and post-Games (Post-Game Years). Olympic is equal to one if firm $i$ is an Olympic sponsor or is mentioned in the local media that will benefit from the Olympics and zero otherwise. The base period in column (1) is the pre-announcement period (the three years before the announcement of the Olympic Games) and the post-game years (the three years after the announcement of the Olympic Games). The base period in column (2) is the pre-announcement period (the three years before the announcement of the Olympic Games). Adjusted $\mathrm{R}^{2} \mathrm{~s}$ for the Olympic stocks are obtained from the model: Olympic Stock Return $n_{i, t, k}=\alpha_{0}+\beta i O l y m p i c$ Index $_{t, k}+\varepsilon_{i, t, k}$ (1a). Olympic Stock Return $n_{i, t, k}$ is the daily return for each Olympic stock in country $k$. Olympic Index $x_{t, k}$ is the average of the daily returns of all Olympic firms in each country $k$ excluding firm $i$. Adjusted $\mathrm{R}^{2} \mathrm{~s}$ for the non-Olympic stocks are obtained from the model: Non-Olympic Stock Return $n_{i, t, k}=\alpha_{0}+\beta i N o n-O l y m p i c$ Index $_{t, k}+\varepsilon_{i, t, k}(1 \mathrm{~b})$. Non-Olympic Stock Return $i_{i, t, k}$ is the daily return for each non-Olympic stock in country $k$. Non-Olympic Index $t, k$ is the average of the daily returns of all non-Olympic firms in each country $k$ excluding firm $i$. Log of Total Assets is the natural logarithm of total assets. ROA is net income available to common divided by average assets. CFO is Cash Flow from Operating Activities divided by average assets. The sample consists of 211 Olympic stocks and 211 non-Olympic stocks that were publicly traded during the Olympic winning bid announcement. All continuous variables are winsorized at 1 and $99 \%$. T-statistics in parenthesis and stars denote statistical significance from twotailed tests when we do not have directional predictions and one-tailed tests for directional predictions. ***, **, and * denote statistical significance at the one, five, and ten percent levels, respectively. See Appendix B for detailed variable definitions. 
TABLE 6

Average Number of Firm-Specific Olympic Media Mentions for each Olympic Period

\begin{tabular}{|c|c|c|c|c|}
\hline & Years & $\begin{array}{l}\text { Media Mentions } \\
\text { Olympic }\end{array}$ & $\begin{array}{l}\text { Media Mentions } \\
\text { Non-Olympic }\end{array}$ & Difference \\
\hline $\begin{array}{l}\text { Pre-Announcement } \\
\text { Years }\end{array}$ & The 3 years prior to the announcement & 1.744 & 0.588 & $\begin{array}{l}1.156 * * * \\
(0.00)\end{array}$ \\
\hline Middle Years & The 7 years after the announcement & 7.453 & 3.022 & $\begin{array}{l}\text { 4.431*** } \\
(0.00)\end{array}$ \\
\hline Olympic Years & The year of the Olympic games & 30.986 & 12.938 & $\begin{array}{l}18.047 * * * \\
(0.00)\end{array}$ \\
\hline Post-Game Years & The 3 years after the Olympic games & 16.032 & 5.425 & $\begin{array}{l}10.606 * * * \\
(0.00)\end{array}$ \\
\hline \multirow{5}{*}{ Predicted Sign } & $\begin{array}{l}\text { Pre-Announcement Years } \\
\text { v.s. Middle Years }\end{array}$ & $\begin{array}{l}5.709 \\
(0.00)\end{array}$ & $\begin{array}{l}2.434 \\
(0.00)\end{array}$ & $\begin{array}{l}\text { 3.274*** } \\
(\mathbf{0 . 0 0 )}\end{array}$ \\
\hline & Middle Years & 23.532 & 9.916 & $13.616 * * *$ \\
\hline & v.s. Olympic Years & $(\mathbf{0 . 0 0 )}$ & $(\mathbf{0 . 0 0 )}$ & $(\mathbf{0 . 0 0 )}$ \\
\hline & $\begin{array}{l}\text { Olympic Years } \\
\text { v.s. Post-Game Years }\end{array}$ & $\begin{array}{c}-14.954 \\
(0.00)\end{array}$ & $\begin{array}{l}-7.513 \\
(0.00)\end{array}$ & $\begin{array}{l}-7.441 * * \\
(0.05)\end{array}$ \\
\hline & & $\mathrm{N}=208$ & $\mathrm{~N}=208$ & \\
\hline
\end{tabular}

This table presents descriptive results for the mean number of Olympic media mentions for Olympic and non-Olympic stocks. The number of media mentions for each firm are obtained from Factiva. Media mentions for each firm are obtained from Factiva and are the number of media articles during the calendar year in the local news sources for each firm that include the words "Olympic" or "Olympics". The top four rows in each panel present the average Factiva mentions related to "Olympic" or "Olympics" for all Olympic and non-Olympic stocks. The bottom rows present changes in media mentions over the respective periods. Difference-indifference represents the difference between Olympic and non-Olympic stocks. P-values in parenthesis denote statistical significance from one-sided t-tests of changes in $\mathrm{R}^{2}$.***,**, and * denote statistical significance at the one, five, and ten percent levels, respectively. The all Olympics combined sample consists of 208 Olympic stocks and 208 non-Olympic stocks that were publicly traded during the Olympic winning bid announcement. 5 Olympic and their corresponding 5 non-Olympic stocks dropped from the full sample due to Factiva data restrictions. See Appendix B for detailed variable definitions. 
TABLE 7

Abnormal Volume and Abnormal Returns

Panel A: Abnormal volume at the Olympic winning bid announcement dates, initial Olympic stock classification dates by media, and during the Olympic Games

\begin{tabular}{|c|c|c|c|c|c|}
\hline Period & $\begin{array}{l}\text { Predicted } \\
\text { Sign }\end{array}$ & $\begin{array}{l}\text { Observations } \\
\text { (Olympic and } \\
\text { non-Olympic) }\end{array}$ & $\begin{array}{c}\text { Abnormal } \\
\text { Volume } \\
\text { Olympic }\end{array}$ & $\begin{array}{c}\text { Abnormal } \\
\text { Volume } \\
\text { non-Olympic }\end{array}$ & $\begin{array}{l}\text { Abnormal } \\
\text { Volume } \\
\text { Difference }\end{array}$ \\
\hline Winning bid announcement dates & $(+)$ & 426 & 0.424 & -0.052 & $\begin{array}{l}\mathbf{0 . 4 7 8 * * *} \\
(\mathbf{0 . 0 0 )}\end{array}$ \\
\hline $\begin{array}{l}\text { Initial Olympic stock classification } \\
\text { dates by media }\end{array}$ & $(+)$ & 264 & 0.363 & -0.055 & $\begin{array}{l}0.418 * * * \\
(0.01)\end{array}$ \\
\hline During the Olympic Games & (n.a.) & 426 & -0.281 & -0.234 & $\begin{array}{l}-0.047 \\
(0.56)\end{array}$ \\
\hline
\end{tabular}

Panel B: Abnormal return volatility at the Olympic winning bid announcement dates, initial Olympic stock classification dates by media, and during the Olympic Games

\begin{tabular}{|c|c|c|c|c|c|}
\hline Period & $\begin{array}{l}\text { Predicted } \\
\text { Sign }\end{array}$ & $\begin{array}{l}\text { Observations } \\
\text { (Olympic and } \\
\text { non-Olympic) }\end{array}$ & $\begin{array}{l}\text { U-statistic } \\
\text { Olympic }\end{array}$ & $\begin{array}{c}\text { U-statistic } \\
\text { Non-Olympic }\end{array}$ & $\begin{array}{l}\text { U-statistic } \\
\text { Difference }\end{array}$ \\
\hline Winning bid announcement dates & $(+)$ & 414 & 3.345 & 1.434 & $\begin{array}{l}1.912 * * \\
(0.04)\end{array}$ \\
\hline $\begin{array}{l}\text { Initial Olympic stock classification } \\
\text { dates by media }\end{array}$ & $(+)$ & 270 & 2.323 & 0.897 & $\begin{array}{l}1.426 * * \\
(0.05)\end{array}$ \\
\hline During the Olympic Games & (n.a.) & 414 & 1.006 & 0.768 & $\begin{array}{l}0.238 \\
(0.11) \\
\end{array}$ \\
\hline
\end{tabular}

This table presents descriptive results for abnormal volume and abnormal returns at the winning bid announcement dates, initial Olympic stock classification dates by the media, and during the Olympic Games. Panel A presents the results for abnormal volume. Abnormal volume is defined as the average volume at the event period (day - 1 , day +1$)$ minus the average volume in the non-event period and divided by standard deviation of volume in the non-event period. The event periods are either the Olympics announcement date, the media mention date, or the Olympic game dates. The non-event or estimation period is defined as the period from 130 to 10 days prior to the event and days 10 to 130 days after the event. Panel B presents the results for abnormal return volatility. U-statistic is calculated by dividing the squared residual returns by the variance of the residual returns following Beaver (1968). We estimate the market model with daily stock returns in the non-event or estimation period, obtain estimates of the intercept and slope coefficient, $a_{i}$ and $b_{i}$, and calculate the residual returns and variance. T-statistics in parenthesis and stars denote statistical significance from two-tailed tests when we do not have directional predictions and one-tailed tests for directional predictions. $* * * * *$, and $*$ denote statistical significance at the one, five, and ten percent levels, respectively. See Appendix B for detailed variable definitions. 
TABLE 8

Multivariate analysis of Comovement and Media Mentions

\begin{tabular}{|c|c|c|c|}
\hline \multirow[t]{2}{*}{ Dependent Variable: } & \multirow{2}{*}{$\begin{array}{l}\text { Predicted } \\
\text { Sign }\end{array}$} & \multicolumn{2}{|c|}{ Comovement } \\
\hline & & $\begin{array}{c}\mathbf{R}^{2} \text { Model1 } \\
(1)\end{array}$ & $\begin{array}{c}\mathbf{R}^{2} \text { Model1 } \\
(2)\end{array}$ \\
\hline Olympic & & & $\begin{array}{l}0.050 * * * \\
(5.87)\end{array}$ \\
\hline Olympic Years & & & $\begin{array}{l}0.058 * * * \\
(7.73)\end{array}$ \\
\hline Olympic * Middle Years and Olympic Years & & & $\begin{array}{l}0.018^{*} \\
(1.74)\end{array}$ \\
\hline Log Media Mentions & $(+)$ & $\begin{array}{l}0.005^{* *} \\
(1.99)\end{array}$ & $\begin{array}{l}0.008 * * \\
(1.76)\end{array}$ \\
\hline Olympic * Log Media Mentions & & & $\begin{array}{l}-0.006 \\
(-1.09)\end{array}$ \\
\hline Olympic Years * Log Media Mentions & & & $\begin{array}{l}0.001 \\
(0.12)\end{array}$ \\
\hline $\begin{array}{l}\text { Olympic * Middle and Olympic Years * } \\
\text { Log Media Mentions }\end{array}$ & $(+)$ & & $\begin{array}{l}0.011 * * \\
(1.97)\end{array}$ \\
\hline Log of Total Assets & & $\begin{array}{l}0.033 * * * \\
(15.88)\end{array}$ & $\begin{array}{l}0.033 * * * \\
(15.82)\end{array}$ \\
\hline ROA & & $\begin{array}{l}-0.002 \\
(-1.10)\end{array}$ & $\begin{array}{l}-0.003 \\
(-1.21)\end{array}$ \\
\hline $\mathrm{CFO}$ & & $\begin{array}{l}-0.039 \\
(-1.62)\end{array}$ & $\begin{array}{l}-0.040 \\
(-1.64)\end{array}$ \\
\hline Observations & & 4,148 & 4,148 \\
\hline Unique Firms & & 416 & 416 \\
\hline R-squared & & 0.655 & 0.642 \\
\hline Country FEs & & YES & YES \\
\hline Year FEs & & YES & YES \\
\hline Industry FEs & & YES & YES \\
\hline
\end{tabular}

This table reports the results of regression of adjusted $\mathrm{R}^{2}$ from Model (1) on the number of media mentions and indicators for the Middle and Olympic Years. The base period is the three years prior to the winning bid announcement (Pre-Announcement Years) and the three years following the Olympics (Post-Game Years). Adjusted $\mathrm{R}^{2} \mathrm{~s}$ for the Olympic stocks are obtained from the model 1a: Olympic Stock Return $i_{i, t, k}=\alpha_{0}+$ BiOlympic Index ${ }_{t, k}+\varepsilon_{i, t, k}$ (1a). Olympic Stock Return $i_{i, t, k}$ is the daily return for each Olympic stock in country $k$. Olympic Indext, is the average of the daily returns of all Olympic firms in each country $k$ excluding firm $i$. Adjusted $\mathrm{R}^{2} \mathrm{~s}$ for the non-Olympic stocks are obtained from the model 1b: Non-Olympic Stock Return $i, t, k=\alpha 0+$ BiNon-Olympic Index $x_{t, k}+\varepsilon_{i, t, k}$ (1b). Non-Olympic Stock Return ${ }_{i, t, k}$ is the daily return for each non-Olympic stock in country $k$. Non-Olympic Index $x_{t, k}$ is the average of the daily returns of all non-Olympic firms in each country $k$ excluding firm $i$. Media mentions are the number of media articles in Factiva during the calendar year in the local news sources for each firm that include the words "Olympic" or "Olympics". We search only local news sources and in the local language to increase the likelihood that these media outlets are read by domestic investors. Log Media Mentions is the natural log of (1+the number of Factiva media mentions). Log of Total Assets is the natural logarithm of total assets. ROA is net income available to common divided by average assets. CFO is Cash Flow from Operating Activities divided by average assets. The sample consists of 208 Olympic stocks and 208 non-Olympic stocks that were publicly traded during the Olympic winning bid announcement. All continuous variables are winsorized at 1 and $99 \%$. T-statistics in parenthesis and stars denote statistical significance from two-tailed tests when we do not have directional predictions and one-tailed tests for directional predictions. $* * *, * *$, and * denote statistical significance at the one, five, and ten percent levels, respectively. See Appendix B for detailed variable definitions. 
TABLE 9

Difference in Annual Fundamentals between Olympic and non-Olympic Stocks

\begin{tabular}{|c|c|c|c|c|c|}
\hline \multirow{3}{*}{ Dependent Variable: } & \multirow{3}{*}{$\begin{array}{l}\text { Predicted } \\
\text { Sign }\end{array}$} & \multicolumn{4}{|c|}{ Annual Fundamentals } \\
\hline & & \multicolumn{2}{|c|}{$\begin{array}{l}\text { Olympic and Non- } \\
\text { Olympic }\end{array}$} & \multicolumn{2}{|c|}{$\begin{array}{l}\text { Sponsors and Non- } \\
\text { Olympic }\end{array}$} \\
\hline & & $\begin{array}{c}\text { ROE } \\
\text { (1) }\end{array}$ & $\begin{array}{c}\text { Revenue_E } \\
\text { (2) }\end{array}$ & $\begin{array}{c}\text { ROE } \\
(3)\end{array}$ & $\begin{array}{c}\text { Revenue_E } \\
\text { (4) }\end{array}$ \\
\hline Olympic & & $\begin{array}{l}0.004 \\
(0.17)\end{array}$ & $\begin{array}{l}0.110 \\
(0.50)\end{array}$ & $\begin{array}{l}0.030 \\
(0.68)\end{array}$ & $\begin{array}{l}0.808^{*} \\
(1.90)\end{array}$ \\
\hline Middle and Olympic Years & & $\begin{array}{l}0.009 \\
(0.47)\end{array}$ & $\begin{array}{l}-0.215 \\
(-1.31)\end{array}$ & $\begin{array}{l}0.040 \\
(1.30)\end{array}$ & $\begin{array}{l}0.146 \\
(0.59)\end{array}$ \\
\hline Post-Game Years & & $\begin{array}{l}0.075^{* *} \\
(2.56)\end{array}$ & $\begin{array}{l}-0.177 \\
(-0.80)\end{array}$ & $\begin{array}{l}0.133^{*} \\
(1.83)\end{array}$ & $\begin{array}{l}0.276 \\
(0.59)\end{array}$ \\
\hline Olympic * Middle and Olympic Years & $(+)$ & $\begin{array}{l}-0.007 \\
(-0.31)\end{array}$ & $\begin{array}{l}-0.045 \\
(-0.20)\end{array}$ & $\begin{array}{l}-0.035 \\
(-0.85)\end{array}$ & $\begin{array}{l}-0.433 \\
(-1.18)\end{array}$ \\
\hline Olympic * Post-Game Years & (n.a.) & $\begin{array}{l}-0.034 \\
(-1.15)\end{array}$ & $\begin{array}{l}0.034 \\
(0.13)\end{array}$ & $\begin{array}{l}-0.004 \\
(-0.10)\end{array}$ & $\begin{array}{l}-0.031 \\
(-0.09)\end{array}$ \\
\hline Assets_E Lag & & $\begin{array}{l}0.001 \\
(0.31)\end{array}$ & $\begin{array}{l}-0.110 * * * \\
(-3.79)\end{array}$ & $\begin{array}{l}-0.009 \\
(-1.29)\end{array}$ & $\begin{array}{l}-0.108 * \\
(-1.83)\end{array}$ \\
\hline ROE Lag & & $\begin{array}{l}0.332 * * * \\
(6.27)\end{array}$ & $\begin{array}{l}-1.503 * * * \\
(-4.14)\end{array}$ & $\begin{array}{l}0.272 * * * \\
(3.86)\end{array}$ & $\begin{array}{l}-1.934 * * * \\
(-3.47)\end{array}$ \\
\hline Revenue_E Lag & & $\begin{array}{l}0.016^{* * * *} \\
(4.96)\end{array}$ & $\begin{array}{l}0.902 * * * \\
(28.31)\end{array}$ & $\begin{array}{l}0.022^{*} \\
(1.86)\end{array}$ & $\begin{array}{l}0.801 * * * \\
(9.87)\end{array}$ \\
\hline Observations & & 4,398 & 4,398 & 836 & 836 \\
\hline Unique Firms & & 426 & 426 & 84 & 84 \\
\hline R-squared & & 0.27 & 0.662 & 0.466 & 0.670 \\
\hline Country FEs & & Yes & Yes & Yes & Yes \\
\hline Year FEs & & Yes & Yes & Yes & Yes \\
\hline Industry FEs & & Yes & Yes & Yes & Yes \\
\hline
\end{tabular}

This table reports the results of regression of annual ROE and Revenue_E on indicators for the Middle and Olympic Years and Post-Game Years and controls. The base period is the three years prior to the winning bid announcement (Pre-Announcement Years). Middle and Olympic Years are the seven years after the Olympics announcement (Middle years) and the year of the Olympics (Olympic Years). Post-Game Years are the three years after the Olympic Games. Assets_E Lag is the one-year lag of annual assets divided by average book value of equity. ROE Lag is the one-year lag of annual net income divided by average book value of equity. Revenue_E Lag is the one-year lag of annual revenues divided by average book value of equity. The sample in columns (1) and (2) consists of 213 Olympic stocks and 213 non-Olympic stocks that were publicly traded during the Olympic winning bid announcement. The sample in columns (3) and (4) consists of 42 Olympic Sponsors and 42 non-Olympic stocks that were publicly traded during the Olympic winning bid announcement. All continuous variables are winsorized at 1 and $99 \%$. Tstatistics in parenthesis and stars denote statistical significance from two-tailed tests when we do not have directional predictions and one-tailed tests for directional predictions. $* * *, * *$, and $*$ denote statistical significance at the one, five, and ten percent levels, respectively. See Appendix B for detailed variable definitions. 
TABLE 10

Comovements of Fundamentals for the London and Rio Olympics

\begin{tabular}{|c|c|c|c|c|c|}
\hline \multirow[t]{3}{*}{ Dependent Variable: } & \multirow{3}{*}{$\begin{array}{c}\text { Predicted } \\
\text { Sign }\end{array}$} & \multicolumn{4}{|c|}{ Fundamental Comovement } \\
\hline & & \multicolumn{2}{|c|}{ London 2012 Olympics } & \multicolumn{2}{|c|}{ Rio 2016 Olympics } \\
\hline & & $\begin{array}{l}\text { R }^{2} \text { ROE } \\
\text { (1) }\end{array}$ & $\begin{array}{c}\mathbf{R}^{2} \text { Revenue_E } \\
\text { (2) }\end{array}$ & $\begin{array}{c}\text { R }^{2} \text { ROE } \\
\text { (3) }\end{array}$ & $\begin{array}{c}R^{2} \text { Revenue_E } \\
\text { (4) }\end{array}$ \\
\hline Olympic & & $\begin{array}{l}-0.085^{*} \\
(-1.85)\end{array}$ & $\begin{array}{l}-0.057 \\
(-1.19)\end{array}$ & $\begin{array}{l}0.107 \\
(1.57)\end{array}$ & $\begin{array}{l}-0.098 \\
(-0.78)\end{array}$ \\
\hline Middle and Olympic Years & & $\begin{array}{l}0.012 \\
(0.31)\end{array}$ & $\begin{array}{l}0.012 \\
(0.26)\end{array}$ & $\begin{array}{l}0.117 * * \\
(2.48)\end{array}$ & $\begin{array}{l}-0.037 \\
(-0.32)\end{array}$ \\
\hline Post-Game Years & & $\begin{array}{l}-0.062 \\
(-1.41)\end{array}$ & $\begin{array}{l}-0.066 \\
(-1.43)\end{array}$ & $\begin{array}{l}0.032 \\
(0.52)\end{array}$ & $\begin{array}{l}-0.006 \\
(-0.05)\end{array}$ \\
\hline Olympic * Middle and Olympic Years & $(+)$ & $\begin{array}{l}-0.003 \\
(-0.06)\end{array}$ & $\begin{array}{l}-0.004 \\
(-0.07)\end{array}$ & $\begin{array}{l}-0.014 \\
(-0.18)\end{array}$ & $\begin{array}{l}0.055 \\
(0.42)\end{array}$ \\
\hline Olympic * Post-Game Years & (n.a.) & $\begin{array}{l}-0.003 \\
(0.93)\end{array}$ & $\begin{array}{l}0.037 \\
(0.62)\end{array}$ & $\begin{array}{l}-0.079 \\
(-1.09)\end{array}$ & $\begin{array}{l}0.045 \\
(0.30)\end{array}$ \\
\hline Assets_E & & $\begin{array}{l}-0.006 \\
(-0.85)\end{array}$ & $\begin{array}{l}-0.005 \\
(-0.94)\end{array}$ & $\begin{array}{l}0.013 \\
(0.60)\end{array}$ & $\begin{array}{l}-0.011 \\
(-0.27)\end{array}$ \\
\hline ROE & & $\begin{array}{l}0.104 \\
(1.12)\end{array}$ & $\begin{array}{l}-0.047 \\
(-0.49)\end{array}$ & $\begin{array}{l}-0.468 \\
(-0.58)\end{array}$ & $\begin{array}{l}-1.323 \\
(-1.20)\end{array}$ \\
\hline Revenue_E & & $\begin{array}{l}-0.007 \\
(-0.72)\end{array}$ & $\begin{array}{l}-0.002 \\
(-0.24)\end{array}$ & $\begin{array}{l}-0.082 \\
(-0.84)\end{array}$ & $\begin{array}{l}0.188 \\
(1.10)\end{array}$ \\
\hline Observations & & 354 & 354 & 90 & 90 \\
\hline Unique Firms & & 118 & 118 & 30 & 30 \\
\hline R-squared & & 0.186 & 0.218 & 0.526 & 0.311 \\
\hline Industry FEs & & Yes & Yes & Yes & Yes \\
\hline
\end{tabular}

This table presents regressions of fundamental comovement $\left(\mathrm{R}^{2} \mathrm{ROE}\right.$ and $\mathrm{R}^{2}$ Revenue_E for each period) for the London and Rio Olympics on indicators for the Middle and Olympic Years, Post-Game Years, and controls. The base period is the 20 quarters prior to the winning bid announcement (Pre-Announcement Years). Middle and Olympic Years are the 32 quarters from the Olympic announcement to the end of the Olympic games. Post-Game Years are the 20 quarters after the Olympic games. Assets_E is the average value per period (Pre-Announcement Years, Middle and Olympic Years, and Post-Game Years) of the semi-annual (quarterly) assets divided by the average book value of equity. ROE is the average value per period (Pre-Announcement Years, Middle and Olympic Years, and Post-Game Years) of the semi-annual (quarterly) net income divided by the average book value of equity. Revenue_E is the average value per period (Pre-Announcement Years, Middle and Olympic Years, and Post-Game Years) of the semi-annual (quarterly) revenue divided by the average book value of equity. Columns (1) and (2) presents results for the London 2012 Olympics using semi-annual data. Columns (3) and (4) presents results for the Rio 2016 Olympics using quarterly data. The measures of fundamental comovement are obtained from Models 5a and 5b in which we regress the Olympic (non-Olympic) fundamental return (ROE and Revenue_E) on an Olympic (non-Olympic) Fundamental Index. ROE is semi-annual (quarterly) net income scaled by average book value of equity. Revenue_E is semi-annual (quarterly) revenue scaled by average book value of equity. Olympic (non-Olympic) Fundamentals Index for each half-year (quarter) are the average of the semi-annual (quarterly) fundamentals for all Olympic firms (non-Olympic) excluding firm $i$. T-statistics in parenthesis and stars denote statistical significance from two-tailed tests when we do not have directional predictions and one-tailed tests for directional predictions. $* * *, * *$, and $*$ denote statistical significance at the one, five, and ten percent levels, respectively. The London sample consists of 59 Olympic and 59 non-Olympic stocks that were publicly traded during the Olympic winning bid announcement and have at least 10 non-missing ROE and Revenue_E per period. The Rio sample consists of 15 Olympic and 15 non-Olympic stocks that were publicly traded during the Olympic winning bid announcement and have at least 10 non-missing ROE and Revenue_E per period. We do not include results for Sydney 2000, Athens 2004 and Beijing 2008 Olympics because of missing interim data in the Pre-Announcement Years. See Appendix B for detailed variable definitions. 
TABLE 11

Comovement and Retail Ownership

Panel A: Comovements of Olympic Stocks by High and Low Retail Ownership

\begin{tabular}{|c|c|c|c|c|c|}
\hline & \multicolumn{2}{|r|}{ Years } & $\mathbf{R}^{2}$ High Retail & $\mathbf{R}^{2}$ Low Retail & Diff \\
\hline \multirow{4}{*}{$\begin{array}{l}\text { Pre-Announcement } \\
\text { Middle Years } \\
\text { Olympic Years } \\
\text { Post-Game Years }\end{array}$} & \multicolumn{2}{|c|}{ The 3 years prior to the announcement } & 0.282 & 0.233 & 0.049 \\
\hline & \multicolumn{2}{|c|}{ The 7 years after the announcement } & 0.323 & 0.266 & 0.057 \\
\hline & \multicolumn{2}{|c|}{ The year of the Olympic games } & 0.401 & 0.226 & 0.176 \\
\hline & \multicolumn{2}{|c|}{ The 3 years after the Olympic games } & 0.276 & 0.160 & 0.116 \\
\hline \multirow{4}{*}{ Predicted Sign } & $\mathrm{R}^{2}$ Olympic $(+)$ & $\begin{array}{l}\text { Pre-Announcement } \\
\text { v.s. Middle Years }\end{array}$ & $\begin{array}{l}0.041 \\
(0.04)\end{array}$ & $\begin{array}{l}0.033 \\
(0.17)\end{array}$ & $\begin{array}{l}0.008 * * \\
(0.03)\end{array}$ \\
\hline & $\mathrm{R}^{2}$ Olympic $(+)$ & $\begin{array}{l}\text { Middle Years } \\
\text { v.s. Olympic Years }\end{array}$ & $\begin{array}{l}0.079 \\
(0.01)\end{array}$ & $\begin{array}{l}-0.040 \\
(0.06)\end{array}$ & $\begin{array}{l}\mathbf{0 . 1 1 9} * * * \\
(\mathbf{0 . 0 1 )}\end{array}$ \\
\hline & \multirow[t]{2}{*}{$\mathrm{R}^{2}$ Olympic (-) } & $\begin{array}{l}\text { Olympic Years } \\
\text { v.s. Post-Game Years }\end{array}$ & $\begin{array}{l}-0.126 \\
(0.00)\end{array}$ & $\begin{array}{l}-0.065 \\
(0.00)\end{array}$ & $\begin{array}{l}-0.060 * * \\
(0.04)\end{array}$ \\
\hline & & & $\mathrm{N}=110$ & $\mathrm{~N}=79$ & \\
\hline
\end{tabular}

Panel B: Multivariate Analysis of Comovement and Retail Ownership

\begin{tabular}{|c|c|c|}
\hline Dependent Variable: & $\begin{array}{c}\text { Predicted } \\
\text { Sign }\end{array}$ & $\mathbf{R}^{2}$ Model1 \\
\hline Olympic & & $\begin{array}{l}0.037 \text { *** } \\
(2.62)\end{array}$ \\
\hline Middle Years & & $\begin{array}{l}0.057 * * * \\
(5.14)\end{array}$ \\
\hline Olympic Years & & $\begin{array}{l}0.055^{* * * *} \\
(3.64)\end{array}$ \\
\hline Post Game Years & & $\begin{array}{l}-0.007 \\
(-0.66)\end{array}$ \\
\hline Olympic * Middle Years & & $\begin{array}{l}0.008 * * \\
(1.74)\end{array}$ \\
\hline Olympic * Olympic Years & & $\begin{array}{l}0.010 \\
(1.41)\end{array}$ \\
\hline Olympic * Post-Game Years & & $\begin{array}{l}0.003 \\
(0.16)\end{array}$ \\
\hline High Retail & & $\begin{array}{l}0.003 * * \\
(1.97)\end{array}$ \\
\hline Olympic* Middle Years* High Retail & $(+)$ & $\begin{array}{l}0.040 * * \\
(1.71)\end{array}$ \\
\hline Olympic * Olympic Years* High Retail & $(+)$ & $\begin{array}{l}0.010 * * \\
(1.79)\end{array}$ \\
\hline Olympic * Post-Game Years* High Retail & (n.a.) & $\begin{array}{l}-0.009 \\
(-0.41)\end{array}$ \\
\hline Control Variables & & \\
\hline Observations & & 4,222 \\
\hline Unique Firms & & 422 \\
\hline R-squared & & 0.64 \\
\hline Country FEs & & Yes \\
\hline Year FEs & & Yes \\
\hline Industry FEs & & Yes \\
\hline
\end{tabular}


This table reports cross sectional results for comovement for high and low retail ownership. Panel A presents the mean value of comovements $\left(\mathrm{R}^{2}\right)$ from firm-specific regressions using Model 1 for Olympic stocks over three years prior to the Olympics winning bid announcement year, seven years prior to the Olympic Games, during the Olympic games, and three years after the Games, separately. $\mathrm{R}^{2}$ High Retail is estimated using Model 1 for stocks for which the retail investors hold more than $50 \%$ of the shares outstanding in the year of the Olympics announcement. $\mathrm{R}^{2}$ Low Retail is estimated using Model 1 for stocks for which the retail investors hold less than $50 \%$ of the shares outstanding in the year of the Olympics announcement. The top four rows in Panel A present the average $\mathrm{R}^{2}$ of Olympic firm-specific regressions of daily returns on an Olympic index (Model 1) for each of the four foregoing windows. Adjusted $\mathrm{R}^{2} \mathrm{~s}$ for the Olympic stocks are obtained from the model: Olympic Stock Return $n_{i, t, k}=\alpha_{0}+\beta i O l y m p i c$ Index $_{t, k}+\varepsilon_{i, t, k}$ (1a). Olympic Stock Return ${ }_{i, t, k}$ is the daily return for each Olympic stock in country $k$. Olympic Index $x_{t, k}$ is the average of the daily returns of all Olympic firms in each country $k$ excluding firm $i$. Adjusted $\mathrm{R}^{2} \mathrm{~s}$ for the non-Olympic stocks are obtained from the model: Non-Olympic Stock Return ${ }_{i, t, k}=\alpha_{0}+\beta i N o n-O l y m p i c$ Index $x_{t, k}+\varepsilon_{i, t, k}$ (1b). Non-Olympic Stock Return $n_{i, t, k}$ is the daily return for each non-Olympic stock in country $k$. Non-Olympic Index $t_{t, k}$ is the average of the daily returns of all non-Olympic firms in each country $k$ excluding firm $i$. There are 110 unique Olympics stocks classified as high retail in the year of the Olympics announcement and 79 unique Olympic stocks classified as low retail in the year of the Olympics announcement. Panel B reports the results of regression of the adjusted $\mathrm{R}^{2}$ from Models (1a and $1 \mathrm{~b}$ ) on an indicator for Olympic or non-Olympic stocks (Olympic) and indicators for the different Olympic periods: middle years (Middle Years), Olympic years (Olympic Years), and post-Games (Post-Game Years). Olympic is equal to one if firm $i$ is an Olympic sponsor or is mentioned in the local media that will benefit from the Olympics and zero otherwise. The base period is the Pre-Announcement Years - the three years before the announcement of the Olympic Games. Controls are Log of Total Assets, ROA, and CFO. Log of Total Assets is the natural logarithm of total assets. ROA is net income available to common divided by average assets. CFO is Cash Flow from Operating Activities divided by average assets. The sample consists of 211 Olympic stocks and 211 non-Olympic stocks that were publicly traded during the Olympic winning bid announcement. All continuous variables are winsorized at 1 and $99 \%$. T-statistics in parenthesis and stars denote statistical significance from two-tailed tests when we do not have directional predictions and one-tailed tests for directional predictions. $* * * * *$, and $*$ denote statistical significance at the one, five, and ten percent levels, respectively. See Appendix B for detailed variable definitions. 